\title{
METHANE EMISSIONS FROM WETLANDS IN THE MIDBOREAL REGION OF NORTHERN ONTARIO, CANADA ${ }^{1}$
}

\author{
J. L. BubIER AND T. R. MOORE \\ Department of Geography, McGill University, Montreal, Quebec, Canada H3A 2K6 \\ N. T. ROULET \\ Department of Geography, York University, 4700 Keele Street, North York, Ontario, Canada M3J 1P3
}

\begin{abstract}
Methane $\left(\mathrm{CH}_{4}\right)$ fluxes were measured by a static chamber technique from May to October 1991 at 19 wetland sites near Cochrane, northern Ontario, representative of the Clay Belt Midboreal region of central Canada. Seasonal average fluxes of $\mathrm{CH}_{4}$ from the peatlands ranged from 0.4 to $67.5 \mathrm{mg} \cdot \mathrm{m}^{-2} \cdot \mathrm{d}^{-1}\left(0.06-10.1 \mathrm{~g} \cdot \mathrm{m}^{-2} \cdot \mathrm{yr}^{-1}\right)$. Beaver ponds showed the highest fluxes of $\mathrm{CH}_{4}$, from both the open water section (seasonal average 290 $\left.\mathrm{mg} \cdot \mathrm{m}^{-2} \cdot \mathrm{d}^{-1}, 44 \mathrm{~g} \cdot \mathrm{m}^{-2} \cdot \mathrm{yr}^{-1}\right)$ and the adjacent marsh areas where the water table rose close to or above the soil surface $\left(91-350 \mathrm{mg} \cdot \mathrm{m}^{-2} \cdot \mathrm{d}^{-1}, 13-53 \mathrm{~g} \cdot \mathrm{m}^{-2} \cdot \mathrm{yr}^{-1}\right)$.

Seasonal mean water table position, particularly at the microtopographic scale of hummock and hollow, explained most of the variability in $\mathrm{CH}_{4}$ emission among wetlands $\left(r^{2}\right.$ $=0.74$ ). Trophic status, such as pore-water $\mathrm{Ca}, \mathrm{Mg}$, and $\mathrm{pH}$ had little correlation with $\mathrm{CH}_{4}$ emissions. Broad-scale peatland classifications that do not account for hydrological differences at the microtopographic level are inadequate for predicting $\mathrm{CH}_{4}$ flux in boreal wetlands, particularly in forested ecosystems where conifer swamps are diverse and comprise the major peatland class. Based on areal estimates of the different wetland types in the Clay Belt, we estimate an annual $\mathrm{CH}_{4}$ flux of $3.4 \mathrm{~g} \cdot \mathrm{m}^{-2} \cdot \mathrm{yr}^{-1}$, generally lower than that used in extrapolations to continental- or global-scale methane budgets.
\end{abstract}

Key words: beaver pond; bog; boreal; carbon cycle; $\mathrm{CH}_{4}$; fen; marsh; methane; Ontario, Canada; peatlands; swamp; wetlands.

\section{INTRODUCTION}

Atmospheric methane $\left(\mathrm{CH}_{4}\right)$, an important greenhouse gas that is $\approx 21$ times as radiatively effective as $\mathrm{CO}_{2}$, has increased $1 \%$ per year during the last century, although the rate may be slowing (Khalil and Rasmussen 1989, 1990, Steele et al. 1992). Current global estimates of methane emissions from wetlands north of $40^{\circ} \mathrm{N}$ range from 22 to $70 \mathrm{Tg} / \mathrm{yr}$ or $4-16 \%$ of the annual atmospheric burden (Matthews and Fung 1987, Aselmann and Crutzen 1989, Fung et al. 1991). The large range in these estimates is due to the high interand intrasite spatial variability (Crill et al. 1988, Moore et al. 1990, Bartlett et al. 1992, Morrissey and Livingston 1992, Dise 1993), an incomplete understanding of the environmental factors that control $\mathrm{CH}_{4}$ flux, and an insufficient database for determining the extent of ecologically different peatlands in the northern latitudes. To better assess the role of northern wetlands in the global $\mathrm{CH}_{4}$ cycle, we need a better understanding of the processes controlling $\mathrm{CH}_{4}$ emissions.

Boreal wetlands $\left(45^{\circ}-60^{\circ} \mathrm{N}\right)$ comprise over half the wetland area in the northern hemisphere (Aselmann and Crutzen 1989). In North America, measurements of $\mathrm{CH}_{4}$ emissions have been made in four areas: northern Minnesota (Harriss et al. 1985, Crill et al. 1988, Dise 1993); Schefferville, Quebec (Moore and Knowles

${ }^{1}$ Manuscript received 4 December 1992; revised 25 March 1993; accepted 3 April 1993.
1990, Moore et al. 1990); the Hudson Bay Lowland (Moore et al., in press, Roulet et al., in press); and central Alberta (Vitt et al. 1990). Significant differences in $\mathrm{CH}_{4}$ flux are reported from these regions, making global estimates uncertain. A recent study of boreal wetlands in southern Ontario (Roulet et al. 1992) described $\mathrm{CH}_{4}$ fluxes from low boreal Canadian wetlands. The present study deals with $\mathrm{CH}_{4}$ emissions from the Clay Belt region of northern Ontario, one of the largest expanses of wetland (over $78000 \mathrm{~km}^{2}$ ) representing the midboreal region (Fig. 1).

Methane is produced in the waterlogged portions of wetland soils and transported to the surface by diffusion, ebullition, and through plant structures (Cicerone and Oremland 1988, Whiting and Chanton 1992). As much as $80-90 \%$ of the $\mathrm{CH}_{4}$ produced in the anaerobic zone, however, may be oxidized before it reaches the atmosphere (Yavitt et al. 1988, King et al. 1990, Fechner and Hemond 1992). The net $\mathrm{CH}_{4}$ flux, then, is a result of a complex set of interracting controls on production, transport, and consumption. Although soil temperature may explain some of the seasonal variation within sites (Svensson and Rosswall 1984, Crill et al. 1988, Bartlett et al. 1992, Morrissey and Livingston 1992), seasonal mean water table appears to be a better indicator of differences among sites (Moore et al. 1990, Roulet et al. 1992, Moore and Roulet 1993, Dise et al., in press).

Vegetation associations, which often reflect seasonal 


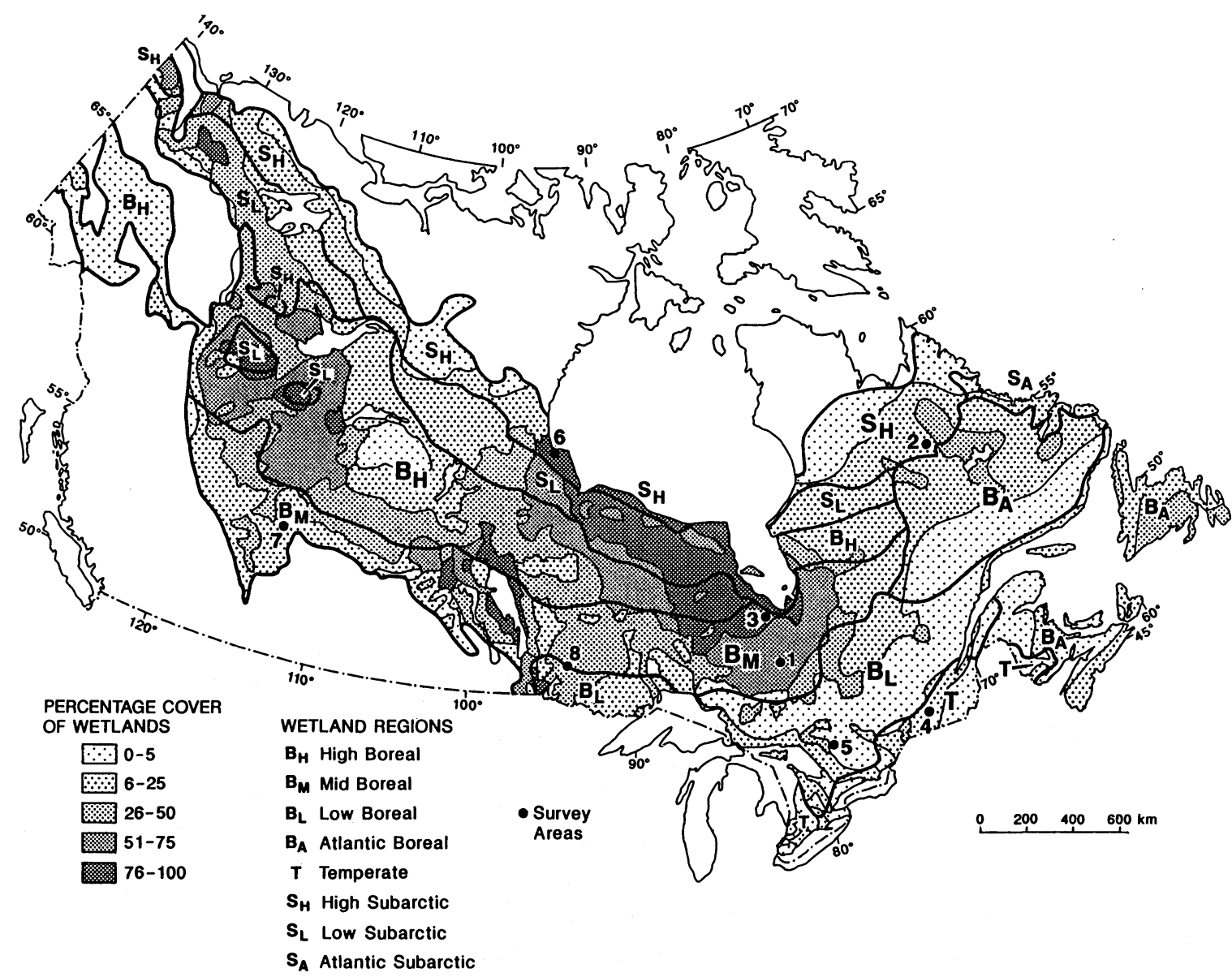

FIG. 1. Wetland regions of Canada with major methane study areas shown across boreal/subarctic regions. Study sites include: (1) Clay Belt region, Ontario (this study); (2) Schefferville, Quebec; (3) Moosonee, Ontario; (4) Montreal, Quebec; (5) Dorset, Ontario; (6) Churchill, Manitoba; (7) Edmonton, Alberta; (8) Experimental Lakes Area, Ontario.

water position as well as nutrient regimes, have been found to be an empirical indicator of $\mathrm{CH}_{4}$ flux (Svensson and Rosswall 1984, Bartlett et al. 1989, Whalen and Reeburgh 1990). Yet the spatial variability of $\mathrm{CH}_{4}$ flux is often high, even within ecologically similar wetlands (Moore et al. 1990, Morrissey and Livingston 1992). The variation may be partly due to small-scale hummock and hollow microtopography (Lindholm and Markkula 1984, Verry 1984), suggesting that small differences in water table position are important. Global estimates of $\mathrm{CH}_{4}$ flux are based on broad wetland classifications of bog, swamp, and fen, which are determined largely by nutrient regime and physiognomic characteristics in vegetation (Matthews and Fung 1987). Water table position, except for obvious areas of open water, and microtopography are rarely incorporated even though these factors vary within the broad ecological classes.

We determined $\mathrm{CH}_{4}$ flux from a series of wetlands based on a predetermined ecological classification for the Clay Belt region of Canada in order to (1) determine environmental correlations with $\mathrm{CH}_{4}$ flux to explain inter- and intrasite variability; (2) contribute to more accurate global estimates; (3) assess the utility of broadscale wetland classifications for predicting $\mathrm{CH}_{4}$ flux.

\section{STUdy AREA}

The Clay Belt of northeastern Ontario is an area with extensive wetland coverage owing to impermeable soils that developed from sediments deposited in the last glacial and postglacial period. The clay sediments were deposited from the inundation of the area by proglacial Lake Barlow-Ojibway and by the subsequent Cochrane Readvance (Boissoneau 1966, Riley 1987). In the northern part of the area, the clay plain is occasionally interrupted by north-south trending eskers.

\section{Climatic context}

The regional climate of the Clay Belt is characterized by long, cold winters and short, cool summers with mean January temperatures of $-24^{\circ}$ to $-10^{\circ} \mathrm{C}$, mean July temperatures of $10^{\circ}-24^{\circ} \mathrm{C}$, and mean annual pre- 
TABLE 1. Percentage cover by wetland type based on inventories of the Clay Belt region of northeastern Ontario (Riley 1987).

\begin{tabular}{|c|c|c|c|c|c|c|c|c|}
\hline \multirow[b]{2}{*}{ Region } & \multirow{2}{*}{$\begin{array}{c}\text { Area } \\
\left(\mathrm{km}^{2}\right)\end{array}$} & \multicolumn{2}{|c|}{ Bog } & \multicolumn{2}{|c|}{ Fen } & \multicolumn{2}{|c|}{ Swamp } & \multirow[b]{2}{*}{ Marsh } \\
\hline & & Open & Treed & Open & Treed & Conifer & Thicket & \\
\hline Hearst & 16000 & 1.3 & 8.1 & 4.4 & 6.3 & 58.1 & 16.9 & 4.9 \\
\hline Foleyet & 16400 & 1.1 & 11.7 & 1.6 & 5.4 & 74.7 & 3.2 & 2.1 \\
\hline Cochrane-Kapuskasing & 16000 & 8.8 & 23.2 & 2.1 & 1.2 & 53.2 & 9.2 & 2.3 \\
\hline Timmins-Kirkland Lake & 21000 & 8.2 & 19.6 & 0.4 & 1.5 & 50.6 & 14.9 & 2.2 \\
\hline New Liskaard & 8290 & 2.2 & 3.2 & 2.9 & 0.6 & 60.7 & 28.3 & 1.6 \\
\hline Area-weighted means & & 5.2 & 15.8 & 2.3 & 3.5 & 58.1 & 12.2 & 2.7 \\
\hline
\end{tabular}

TABLE 2. Dominant species by microtopographic group and total number of vascular and bryophyte species for methane sampling sites.

\begin{tabular}{|c|c|c|c|c|c|c|}
\hline \multirow{2}{*}{$\begin{array}{l}\text { Ecolog- } \\
\text { ical } \\
\text { type* }\end{array}$} & \multirow[b]{2}{*}{ Site } & \multirow[b]{2}{*}{ Hummock species } & \multirow[b]{2}{*}{ Hollow species } & \multirow[b]{2}{*}{ Lawn species } & \multicolumn{2}{|c|}{$\begin{array}{l}\text { Total no. } \\
\text { species }\end{array}$} \\
\hline & & & & & $\begin{array}{l}\text { Vascu- } \\
\text { lar }\end{array}$ & $\begin{array}{l}\text { Bryo- } \\
\text { phyte }\end{array}$ \\
\hline$\overline{\mathrm{OgB}}$ & 1 & $\begin{array}{l}\text { Sphagnum fuscum } \\
\text { Picea mariana } \\
\text { Ledum groenlandicum }\end{array}$ & $\begin{array}{l}\text { Sphagnum majus } \\
\text { Carex limosa } \\
\text { Rhynchospora alba }\end{array}$ & $\begin{array}{l}\text { Sphagnum capillifolium } \\
\text { Eriophorum spissum } \\
\text { Carex pauciflora }\end{array}$ & 20 & 11 \\
\hline $\mathrm{cS}$ & 2 & $\begin{array}{l}\text { Sphagnum fuscum } \\
\text { Picea mariana } \\
\text { Ledum groenlandicum }\end{array}$ & $\begin{array}{l}\text { Sphagnum angustifolium } \\
\text { Carex trisperma } \\
\text { Carex pauciflora }\end{array}$ & $\begin{array}{l}\text { Sphagnum capillifolium } \\
\text { Chamaedaphne calyculata } \\
\text { Ledum groenlandicum }\end{array}$ & 19 & 16 \\
\hline OlsF & 3 & $\begin{array}{l}\text { Sphagnum magellanicum } \\
\text { Larix laricina } \\
\text { Ledum groenlandicum }\end{array}$ & $\begin{array}{l}\text { Warnstorfia exannulatus } \\
\text { Sphagnum fallax } \\
\text { Menyanthes trifoliata }\end{array}$ & $\begin{array}{l}\text { Sphagnum angustifolium } \\
\text { Sphagnum warnstorfii } \\
\text { Carex lasiocarpa }\end{array}$ & 32 & 20 \\
\hline TlsF & 4 & $\begin{array}{l}\text { Sphagnum magellanicum } \\
\text { Picea mariana } \\
\text { Larix laricina }\end{array}$ & $\begin{array}{l}\text { Warnstorfia exannulatus } \\
\text { Menyanthes trifoliata }\end{array}$ & $\begin{array}{l}\text { Sphagnum angustifolium } \\
\text { Betula pumila }\end{array}$ & 39 & 16 \\
\hline $\mathrm{OgPF}$ & 5 & $\begin{array}{l}\text { Sphagnum fuscum } \\
\text { Polytrichum strictum } \\
\text { Chamaedaphne calyculata }\end{array}$ & $\begin{array}{l}\text { Sphagnum fallax } \\
\text { Carex oligosperma } \\
\text { Carex limosa }\end{array}$ & $\begin{array}{l}\text { Sphagnum magellanicum } \\
\text { Sphagnum capillifolium } \\
\text { Betula pumila }\end{array}$ & 17 & 9 \\
\hline OlsPF & 6 & $\begin{array}{l}\text { Sphagnum fuscum } \\
\text { Ledum groenlandicum } \\
\text { Chamaedaphne calyculata }\end{array}$ & $\begin{array}{l}\text { Sphagnum fallax } \\
\text { Carex oligosperma } \\
\text { Menyanthes trifoliata }\end{array}$ & $\begin{array}{l}\text { Sphagnum capillifolium } \\
\text { Kalmia polifolia }\end{array}$ & 19 & 12 \\
\hline OlsB & 7 & $\begin{array}{l}\text { Sphagnum fuscum } \\
\text { Ledum groenlandicum } \\
\text { Chamaedaphne calyculata }\end{array}$ & $\begin{array}{l}\text { Sphagnum angustifolium } \\
\text { Carex oligosperma }\end{array}$ & $\begin{array}{l}\text { Sphagnum fuscum } \\
\text { Sphagnum capillifolium } \\
\text { Eriophorum spissum }\end{array}$ & 20 & 11 \\
\hline $\mathrm{ctS}$ & 8 & $\begin{array}{l}\text { Sphagnum magellanicum } \\
\text { Pleurozium schreberi } \\
\text { Picea mariana }\end{array}$ & Cratoneuron filicinum & $\begin{array}{l}\text { Sphagnum russowii } \\
\text { Sphagnum centrale } \\
\text { Alnus rugosa } \\
\text { Carex trisperma }\end{array}$ & 28 & 27 \\
\hline TlsB & 9 & $\begin{array}{l}\text { Sphagnum fuscum } \\
\text { Chamaedaphne calyculata } \\
\text { Picea mariana }\end{array}$ & $\begin{array}{l}\text { Sphagnum angustifolium } \\
\text { Smilacina trifolia }\end{array}$ & & 18 & 10 \\
\hline $\mathbf{M}$ & $10-12$ & & & $\begin{array}{l}\text { Carex aquatilis } \\
\text { Carex rostrata }\end{array}$ & 23 & 6 \\
\hline OlsF & 13 & $\begin{array}{l}\text { Sphagnum fuscum } \\
\text { Juniperus communis } \\
\text { Juniperus horizontalis }\end{array}$ & $\begin{array}{l}\text { Warnstorfia exannulatus } \\
\text { Sphagnum warnstorfii }\end{array}$ & $\begin{array}{l}\text { Sphagnum russowii } \\
\text { Potentilla fruticosa } \\
\text { Scirpus hudsonianus }\end{array}$ & 34 & 19 \\
\hline TlsB & 14 & $\begin{array}{l}\text { Sphagnum fuscum } \\
\text { Picea mariana } \\
\text { Chamaedaphne calyculata }\end{array}$ & $\begin{array}{l}\text { Sphagnum angustifolium } \\
\text { Carex oligosperma } \\
\text { Carex exilis }\end{array}$ & $\begin{array}{l}\text { Sphagnum angustifolium } \\
\text { Pleurozium schreberi } \\
\text { Ledum groenlandicum }\end{array}$ & 18 & 10 \\
\hline OlsB & 15 & $\begin{array}{l}\text { Sphagnum fuscum } \\
\text { Chamaedaphne calyculata }\end{array}$ & $\begin{array}{l}\text { Sphagnum angustifolium } \\
\text { Carex oligosperma }\end{array}$ & $\begin{array}{l}\text { Pleurozium schreberi } \\
\text { Sphagnum fuscum }\end{array}$ & 17 & 11 \\
\hline
\end{tabular}

* $\mathrm{B}=$ Bog; $\mathrm{c}=$ conifer; $\mathrm{F}=$ Fen; $\mathrm{g}=$ graminoid; $\mathrm{ls}=$ low shrub; $\mathrm{M}=$ Marsh; $\mathrm{O}=$ Open; $\mathrm{PF}=$ Poor Fen; $\mathrm{S}=\mathrm{Swamp} ; \mathrm{t}=$ thicket; $\mathrm{T}=$ Treed. 
cipitation of 760-810 mm. One-third of the precipitation falls as snow and the frost-free period averages $88 \mathrm{~d}$. The regional range of annual actual and potential evapotranspiration is $480-530 \mathrm{~mm}$, with a water deficiency near $0 \mathrm{~mm}$ and a surplus ranging from 280 $\mathrm{mm}$ in the west to $330 \mathrm{~mm}$ in the east (Riley 1987).

The 1991 climate summary (Environment Canada) indicates that the May through August mean temperatures were $0.7^{\circ}-2.2^{\circ} \mathrm{C}$ warmer than normal (monthly means 1950-1990), while September and October were $0.9^{\circ}$ and $1.2^{\circ} \mathrm{C}$ cooler than normal, respectively. July and August were $300 \mathrm{~mm}$ and $387 \mathrm{~mm}$ drier than normal, respectively, whereas September and October were wetter than normal by 53 and $239 \mathrm{~mm}$, respectively. Precipitation for May-October 1991 was $88 \%$ of normal; however, for the June-August period, when most of the methane emissions occurred, precipitation was only $72 \%$ of normal.

\section{Characterization of the study sites}

In the 1980 s an extensive peatland inventory was conducted to determine peat resources of the Clay Belt and $77690 \mathrm{~km}^{2}$ of the area were classified through ground surveys and LANDSAT imagery (Riley 1987). The five subareas surveyed (Table 1) are located between $47^{\circ}$ and $50^{\circ} \mathrm{N}$ and between $79^{\circ} 45^{\prime}$ (the QuebecOntario border) and $85^{\circ} \mathrm{W}$. Classification of the peatland types was determined by a four-level hierarchy: formation (bog, swamp, fen, marsh), subformation (open, treed), physiognomic group (graminoid, low shrub, tall shrub), and dominance type (dominant species).

In this study, we chose 12 sites representative of the different peatland subformations and four adjacent beaver ponds with associated marshes in order to estimate $\mathrm{CH}_{4}$ emissions and to scale up to the larger Clay Belt region. All of the sites chosen for $\mathrm{CH}_{4}$ sampling were located in the Cochrane-Kapuskasing and Timmins-Kirkland study areas of the Ontario Peatland Inventory (Riley 1987).

Several major attributes of the study sites are shown in Tables 2 and 3. Although the sites varied a great deal, a few generalizations can be made. All of the sites, except the marsh, had significant microtopographic relief. Therefore, plant species, water table position, and chemistry are reported separately for hummocks, hollows, and lawns. With the exception of sites 3, 4, and 8 , all moderately wet, rich sites, Sphagnum fuscum dominated the hummocks. While water table position and species composition of the hollows varied, the hummocks were more similar. Except for the pools in the raised bog at site 1, all the bogs in this study were relatively dry peatlands. Fens had much higher species diversity than bogs, and except for the extremely dry rich fen (site 13), the fens were relatively wet. The moisture regime, species diversity, and water chemistry of the swamps varied widely.

Open bogs. - Sites 1, 7, and 15 were classified as
TABle 3. Seasonal mean depth to water table from ground level and temperature at $20 \mathrm{~cm}$ depth in Clay Belt peatlands. Sites are referenced in Table 2 . Site means are also separated into microtopographic hummock (hk), hollow (hw), and lawn $(\ln )$ groupings.

\begin{tabular}{|c|c|c|c|c|c|c|c|}
\hline \multirow{2}{*}{$\begin{array}{l}\text { Site } \\
\text { no. }\end{array}$} & \multicolumn{4}{|c|}{$\begin{array}{l}\text { Mean water table } \\
\text { depth }(\mathrm{cm})\end{array}$} & \multicolumn{3}{|c|}{$\begin{array}{l}\text { Mean temperature } \\
\text { at } 20 \mathrm{~cm}\left({ }^{\circ} \mathrm{C}\right)\end{array}$} \\
\hline & Site & hk & hw & $\ln$ & Site & $\mathrm{hk}$ & hw \\
\hline 1 & 28.2 & 49.5 & 4.1 & 24.6 & 13.8 & 13.7 & 13.8 \\
\hline 2 & 32.7 & 42.1 & 20.1 & 26.8 & 11.1 & 12.2 & 10.1 \\
\hline 3 & 13.7 & 25.8 & 2.7 & 14.3 & 15.4 & 15.8 & 14.9 \\
\hline 4 & 18.2 & 31.8 & 1.1 & 12.4 & 14.9 & 15.7 & 14.1 \\
\hline 5 & 26.1 & 39.6 & 12.9 & 18.1 & 16.3 & 17.8 & 14.7 \\
\hline 6 & 25.1 & 32.3 & 12.2 & 14.1 & 14.9 & 16.2 & 13.6 \\
\hline 7 & 34.2 & 47.9 & 16.8 & 25.5 & 13.6 & 14.9 & 12.2 \\
\hline 8 & 16.7 & 37.8 & 2.6 & 22.5 & 12.4 & 13.6 & 11.2 \\
\hline 9 & 27.7 & 52.3 & 25.1 & 31.1 & 12.9 & 14.8 & 11.1 \\
\hline 10 & 18.1 & $\ldots$ & $\ldots$ & $\ldots$ & $\ldots$ & $\ldots$ & $\ldots$ \\
\hline 11 & 3.1 & $\ldots$ & $\ldots$ & $\ldots$ & 13.7 & $\ldots$ & $\ldots$ \\
\hline 12 & -5.2 & $\ldots$ & $\ldots$ & $\ldots$ & $\ldots$ & $\ldots$ & $\ldots$ \\
\hline 13 & 35.7 & 81.7 & 21.3 & 43.8 & 12.9 & & 12.9 \\
\hline 14 & 23.3 & 53.4 & 26.1 & 38.1 & 10.8 & & 10.8 \\
\hline 15 & 29.3 & 62.3 & 31.9 & 40.9 & 13.7 & & 13.7 \\
\hline
\end{tabular}

"open" bogs because the trees $>150 \mathrm{~cm}$ in height covered $<10 \%$ of the area (Riley 1987 ). All were very low in species diversity, $\mathrm{pH}(4.0-4.8)$, and $\mathrm{Ca}(0.84-3.60$ $\mathrm{mg} / \mathrm{L}$ ) concentrations, characteristic of bogs (Glaser 1987, Glaser et al. 1990). The main difference among these sites was that site 1 , an open graminoid raised bog, had significant pool development, 5-10 $\mathrm{m}$ in length and 3-4 $\mathrm{m}$ wide. The hummocks at site 1 were large treed islands several metres across, while the hollow measurements were taken at the edges of the pools where Sphagnum majus and Rhynchospora alba dominated. Over half the peatland was covered by a relatively uniform lawn of $S$. capillifolium, Mylia anomola, and Cladopodiella fluitans.

Sites 7 and 15, open low shrub bogs, had well-defined hummocks and hollows, but these were much smaller in size than at site 1 . The hollows and lawns in these two sites were much drier and dominated by Sphagnum angustifolium, a species found higher above the seasonal water table than $S$. majus (Gignac and Vitt 1990, Janssens et al. 1992).

Treed bogs. - Bogs were classified as "treed" if trees over $150 \mathrm{~cm}$ in height had $>10 \%$ coverage and trees $<10 \mathrm{~cm}$ dbh covered $<25 \%$ (Riley 1987). Sites 9 and 14 had low $\mathrm{pH}$ values (4.8 and 4.6), low Ca concentrations $(0.98$ and $3.10 \mathrm{mg} / \mathrm{L})$, and low species diversity, similar to that of the open bogs described above. The hollows in site 14 had a higher cover of Carex oligosperma and $C$. exilis, and higher dominance of Pleurozium schreberi in the lawns, but were still characteristic of oligotrophic peatlands (Glaser et al. 1990, Gignac et al. 1991, Jeglum 1991). Both sites were very dry with seasonal mean water levels in the hummocks and hollows at $\approx 52$ and $25 \mathrm{~cm}$ below the peat surface, respectively.

Open fens. - This category included poor as well as 
moderately rich fens. Sites 5 and 6 , open poor fens, had low $\mathrm{pH}$ (4.8), Ca (0.93-1.06 mg/L), and species diversity, but Betula pumila and Menyanthes trifoliata were present, which are indicative of poor fens (sensu Sjörs 1961, 1963). The hollows were relatively wet with a seasonal mean water table position of $12.2-12.9 \mathrm{~cm}$ below the surface and dominated by Sphagnum fallax, a species found closer to the water table than $S$. angustifolium (Janssens et al. 1992).

The moderately rich open fen sites 3 and 13 had high species diversity, higher $\mathrm{pH}$ (5.4-6.3), Ca (2.52-7.17 $\mathrm{mg} / \mathrm{L})$, and $\mathrm{Mg}(0.84-1.50 \mathrm{mg} / \mathrm{L})$, but were very different in other respects. The diversity at site 3 occurred primarily at the graminoid level with six Carex species including C. lasiocarpa and C. chordorrhiza, both fen indicators (Glaser et al. 1990). Site 13 had much higher diversity in the shrub layer with the rich fen indicators Juniperus communis, $J$. horizontalis, and Potentilla fruticosa (Jeglum 1991). Other rich fen indicators at site 13 included Campylium stellatum, Scirpus cespitosus, and Scirpus hudsonianus (Vitt and Chee 1990, Jeglum 1991). Sphagnum warnstorfii, a moderate fen indicator (Vitt and Chee 1990), was found at both sites.

Another striking difference between these two fens was the seasonal mean water table depth. Site 13 was the driest site in the entire study with hummock and hollow water levels at 81.7 and $21.3 \mathrm{~cm}$ below the peat surface, a difference of over $60 \mathrm{~cm}$. Site 3 , on the other hand, was relatively wet, with hummock and hollow water levels of 21.3 and $2.7 \mathrm{~cm}$ below the peat surface. The hollows in site 13 and the hummocks in site 3 had exactly the same seasonal mean depth to water table.

Treed fen. - Site 4 was classified as an intermediate treed fen (Jeglum 1991). Many of the species found in site 3 occurred at site 4 , and $\mathrm{pH}, \mathrm{Ca}, \mathrm{Mg}$, and water table values were also similar. The main difference was the greater dominance of Picea mariana and Larix laricina at site 4 and higher vascular plant diversity. The hummocks at both sites 3 and 4 were dominated by Sphagnum magellanicum, instead of $S$. fuscum as at most other sites, and the seasonal mean water table position in the hummocks $(25.8$ and $31.8 \mathrm{~cm})$ was closer to the peat surface than any of the other sites in this study.

Conifer swamps. - By definition (Riley 1987), swamps were peatlands with trees $>10 \mathrm{~cm}$ dbh attaining $>25 \%$ cover. In the Clay Belt, swamps are the dominant peatland type with $58 \%$ areal coverage overall (Table 1). Yet they vary more widely than any other wetland form in water table regime, nutrients, and species composition. Jeglum (1991), in a recent study of wooded peatlands in the Clay Belt, recognized eight different trophic classes. The two conifer swamps in this study represented the ends of the spectrum. Site 2 was a nutrientpoor swamp with a $\mathrm{pH}$ of $4.1, \mathrm{Ca}$ of $1.54 \mathrm{mg} / \mathrm{L}$, and low species diversity. This site was also very dry. Site 8 , a transitional rich swamp (Jeglum 1991), had much higher $\mathrm{pH}(5.7), \mathrm{Ca}(8.85 \mathrm{mg} / \mathrm{L}), \mathrm{Mg}(1.64 \mathrm{mg} / \mathrm{L})$, and species diversity. The hollows were wet with only 2.6 $\mathrm{cm}$ seasonal mean water table depth, and they were dominated by Cratoneuron filicinum, a fen indicator found in wet seeps (Crum and Anderson 1981).

Beaver ponds and marsh. - The four beaver ponds were located adjacent to one another in ascending position (sites 16-19) along a small stream with water depths varying from 50 to $150 \mathrm{~cm}$ near the impoundments where $\mathrm{CH}_{4}$ was measured. The only marsh in this study was along a transect of $50 \mathrm{~m}$ adjacent to one of the beaver ponds (site 17). Sites 10-12 represented a dry-to-wet marsh gradient with $\approx 10 \mathrm{~m}$ distance between the sites. Seasonal mean water table position ranged from $18 \mathrm{~cm}$ below the surface (site 10) to 5.2 $\mathrm{cm}$ of standing water at the pond edge (site 12). Ca $(13.78 \mathrm{mg} / \mathrm{L})$ and $\mathrm{pH}(6.1)$ values were high, and the area was dominated by Carex rostrata and C. aquatilis. These were the only sites with little microtopography.

\section{Methods}

\section{Methane emission measurements}

Methane was measured using polycarbonate $18-\mathrm{L}$ chambers by the method outlined in Moore and Roulet (1991). The chamber was covered with aluminum foil to reduce heating. Air samples were collected by inserting a $10-\mathrm{mL}$ syringe into a septum stopper in the top of the chamber, pumping the piston several times to mix air in the chamber before an air sample was withdrawn.

The chambers were placed gently into the peat. An initial air sample was taken with the syringe, then a final sample taken after the chamber remained in place for $\approx 2 \mathrm{~h}$. Studies of the $\mathrm{CH}_{4}$ flux from other boreal/ subarctic peatlands have shown that there is a linear increase in $\mathrm{CH}_{4}$ over a 24-h sampling period (Moore and Roulet 1991) so that a 2-h sampling period can be extrapolated to a daily flux. A morning and an afternoon 2-h sampling period was conducted at each site, and the chambers were removed after each sampling period.

At the beaver ponds, the chambers were floated with styrofoam collars and sampled after $2 \mathrm{~h}$. In addition, the chambers were left on the ponds between the 10-d samplings and the air sampled at the end of the 10-d period. An estimate of diffusive $\mathrm{CH}_{4}$ flux from the pond surface was made using dissolved $\mathrm{CH}_{4}$ concentrations and wind speed. During sampling, wind speed was measured with a hand-held anemometer at a height of $1 \mathrm{~m}$ and $30 \mathrm{~mL}$ of pond water from the top $2 \mathrm{~cm}$ was drawn into a $60-\mathrm{mL}$ syringe. An equal volume of air was introduced into the syringe and the mixture shaken vigorously for $2 \mathrm{~min}$ to degas. $\mathrm{CH}_{4}$ concentration was determined in the headspace air and converted to concentration in the water. Calculations of $\mathrm{CH}_{4}$ flux from the open water surface were made using the wind speed and $\mathrm{CH}_{4}$ concentration, based on the formulae described by Crusius and Wanninkhof (in press) and Sebacher et al. (1983). 
Air samples were analyzed within $48 \mathrm{~h}$ of collection. $\mathrm{CH}_{4}$ concentrations were determined on a Shimadzu Mini 2 gas chromatograph, using a 5-mL sample, a 1-mL injection loop, and a Poropak-Q column (80/ $100 \mathrm{mesh}, 3 \mathrm{~m} \times 3 \mathrm{~mm}$ ) at $40^{\circ} \mathrm{C}$. Helium was used as the carrier gas at a flow rate of $30 \mathrm{~mL} / \mathrm{min}$ and $\mathrm{CH}_{4}$ standards of 2 and $500 \mu \mathrm{L} / \mathrm{L}$ were employed. $\mathrm{CH}_{4}$ fluxes were calculated from the difference beteen initial and final concentrations over the 2-h sampling period, corrected for the volume of air in the chamber and air temperature. The accuracy of the gas chromatograph was $\pm 50 \mu \mathrm{L} / \mathrm{m}^{3}$. Fluxes between 0.1 and -0.1 $\mathrm{mg} \cdot \mathrm{m}^{-2} \cdot \mathrm{d}^{-1}$ were not detectable. When the initial concentration exceeded $3 \mu \mathrm{L} / \mathrm{L}$ and the final concentration was $<3 \mu \mathrm{L} / \mathrm{L}$, the sample was rejected. Approximately $2-3 \%$ of the samples were rejected in the drier sites and $9-20 \%$ in the wetter sites where the peat was more prone to disturbance. The rejection rate was not dependent on flux strength or season.

The 12 peatland and 4 beaver pond sites were sampled every $10 \mathrm{~d}$ from mid-May until the end of August 1991 . Three of the sites $(13,14,15)$ were sampled every $5 \mathrm{~d}$. Five of the sites $(6,7,13,14,15)$ were sampled two additional times in September and October to complete the seasonal pattern for the entire snow-free period. Previous studies (Whalen and Reeburgh 1988, 1992, Moore and Knowles 1990, Moore et al. 1990) have shown that within-site $\mathrm{CH}_{4}$ variability is high with coefficients of variation (standard deviation as a percentage of the mean) within ecologically uniform sites ranging from 50 to $200 \%$. Research at subarctic fen sites (Moore et al. 1990) and in the Florida Everglades (Bartlett et al. 1989) has determined that 30-40 chambers are required to lower the standard error as a percentage of the mean to $<15 \%$. In order to address this issue, we used 36 chambers (18 each in the morning and afternoon) at each of the 12 peatland sites on each sampling date. Twelve of the chamber locations at each site were randomly selected and sampled in the same location for the entire season. The remaining 24 were placed randomly in different locations at each sampling date within the overall sampling area $\left(100 \mathrm{~m}^{2}\right)$. Over the sampling season, $\approx 360$ chamber measurements were taken at each site. In the beaver ponds and the three adjacent marsh sites only six chambers were measured during each sampling run.

\section{Environmental variables}

Because of the well-defined microtopography at most of the sites, chambers were located at random within each site and then classified as hummock (hk), hollow (hw), or lawn (ln). The latter designation signified areas intermediate between hummocks and hollows or uniform expanses with little microtopography. In most sites these microhabitats covered about one-third of the area, so that the distribution of these random chamber locations was nearly equal among microhabitats, with each microhabitat type being represented by about one-third of the chamber locations. In other sites (e.g., sites $3,4,9$, and 14) the lawn microhabitats were less abundant than the hummocks and hollows, so that fewer chambers were located in lawn microhabitats at these sites. Seasonal site means were determined by averaging all flux measurements at a site. No weighting was given to microtopographic grouping.

Six groundwater wells, constructed of $3.5-\mathrm{cm}$ perforated ABS pipe, were installed at each site. Water tables were measured on the same day as the $\mathrm{CH}_{4}$ flux sampling. The relative height above the water table of hummocks, hollows, and lawns was determined with a tube level referenced to the nearest well location. Water samples were taken in acid-washed plastic bottles from pools of standing water 3 times during the season. Conductivity and $\mathrm{pH}$ were determined within $24 \mathrm{~h}$. The samples were then filtered, stored at $4^{\circ} \mathrm{C}$, and major cation concentrations $(\mathrm{Ca}, \mathrm{Mg}, \mathrm{Na}, \mathrm{K})$ were determined on an atomic absorption spectrophotometer. Peat temperatures were measured on each $\mathrm{CH}_{4}$ flux sampling date in two hummock and hollow locations at each site at intervals of $10 \mathrm{~cm}$ to a depth of $80 \mathrm{~cm}$, using a thermistor probe (Fenwal JA41J1).

Vegetation was described in $18-2450 \times 50 \mathrm{~cm}$ quadrats per site. Nomenclature for vascular plants follows Fernald (1950); for Sphagnum species, Anderson (1990); and for moss species, Anderson et al. (1990).

\section{RESULTS \\ Spatial variability of $\mathrm{CH}_{4}$ flux}

As expected from results of other studies (Whalen and Reeburgh 1988, 1992, Moore and Knowles 1990, Moore et al. 1990), within-site variability of $\mathrm{CH}_{4}$ flux at each sampling date was very high with coefficients of variation between 86 and $200 \%$ with most sites over $100 \%$. By using 36 chambers per site at each sampling period, however, the standard error as a percentage of the mean ranged from 5 to $40 \%$, with most sites averaging $\approx 20 \%$. All 36 chamber measurements per date were used to calculate the seasonal means as there was no significant difference between the means from the 12 locations where repeated measurements were made and the 24 locations that were changed at each sampling date.

By separating the $\mathrm{CH}_{4}$ flux measurements into hummock, hollow, and lawn within sites, the standard error as a percentage of the mean was $15-25 \%$ (averaging $20 \%$ ), even though fewer chambers were used for each group. This suggests that a lot of the within-site variability in flux can be explained by small spatial differences in water table position relative to the peat surface. Exceptions to this pattern were sites where $\mathrm{CH}_{4}$ fluxes were extremely low, especially for hummocks where standard error as a percentage of the mean was as high as $100 \%$ in two cases (sites 7 and 13 , two very dry sites, an open bog and open fen).

As has been found in other studies, there were weak 


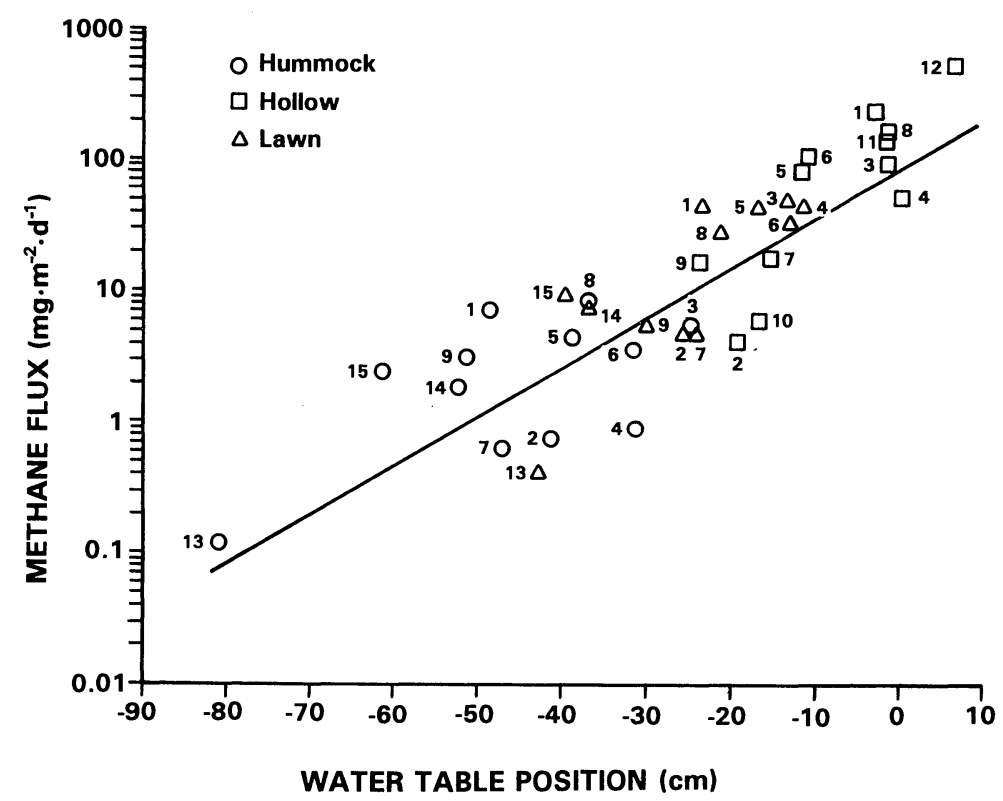

FIG. 2. Relationship between seasonal mean methane flux and mean water table position (WT depth) by site hummock, hollow, and lawn groupings. Site numbers are referenced in Table 2. $\mathrm{Log}_{\mathrm{CH}_{4}}$ flux $=0.037 \mathrm{WT} \operatorname{depth}+1.893\left(r^{2}=0.74 ; P\right.$ $<.001 ; n=36$; standard error of the estimate $=0.431$ ).

statistical relationships between $\mathrm{CH}_{4}$ flux, water table position, and soil temperature within a given wetland site. Analyzing by microhabitat did not improve the relationships. $\mathrm{Log} \mathrm{CH}_{4}$ flux produced a better relationship with these variables, although the relationships were still weak. Log-linear transformations have also improved correlation coefficients at other sites (Crill et al. 1988, Moore and Knowles 1990, Bartlett et al. 1992, Dise et al., in press). In this study, $r^{2}$ for $\log \mathrm{CH}_{4}$ flux with different environmental variables within sites ranged from 0.21 to 0.27 for water table depth, and 0.01 to 0.16 for soil temperature at $20 \mathrm{~cm}$. Multiple regressions with the log of the $\mathrm{CH}_{4}$ flux, water table, and soil temperature only slightly improved the relationships with $r^{2}$ of $0.21-0.38(P<.001)$, suggesting that none of these variables is very useful for predicting the seasonal pattern of $\mathrm{CH}_{4}$ flux within sites.

In spite of these weak relationships within sites, this study shows a highly significant relationship beween seasonal mean water table depth and seasonal mean $\mathrm{CH}_{4}$ flux among the sites (Fig. 2; Table 4). The relationship between the $\log$ of the $\mathrm{CH}_{4}$ flux and water table depth for overall site means was significant $\left(r^{2}=\right.$ $0.56 ; P<.001 ; n=13$ ). But when the sites were subdivided into hummocks, hollows, and lawns, the relationship improved substantially $\left(r^{2}=0.74 ; P<.001\right.$; $n=36$ ).

The seasonal medians (Table 4) were lower than the means at all the sites with mean and median ratios between 1.1:1 and 4.1:1 and an average ratio of 2.6:1. This is similar to patterns observed in Churchill, Manitoba (S. Holland, unpublished manuscript), Fairbanks, Alaska (Whalen and Reeburgh 1992) and Hudson Bay
Lowland near Moosonee, Ontario (Moore et al., in press).

The 1991 seasonal mean peatland $\mathrm{CH}_{4}$ fluxes ranged from 0.4 to $67.5 \mathrm{mg} \cdot \mathrm{m}^{-2} \cdot \mathrm{d}^{-1}$ (Table 4). $\mathrm{CH}_{4}$ fluxes from hollows were 5-60 times higher than hummocks, where the greatest differences in flux also corresponded to greatest differences in water table position relative to the peat surface (Table 3). Lawn fluxes were intermediate between hummocks and hollows, as expected, because of their intermediate water table position. With the exception of a raised bog with pools and one very dry fen, bogs had lower $\mathrm{CH}_{4}$ fluxes than fens, corresponding to the generally lower water table. Swamps varied widely in seasonal $\mathrm{CH}_{4}$ flux.

The open bog sites $(1,7$, and 15) had large differences in $\mathrm{CH}_{4}$ flux. Site 1, the open graminoid raised bog, had a seasonal flux of $67.5 \mathrm{mg} \cdot \mathrm{m}^{-2} \cdot \mathrm{d}^{-1}$ with 5.1 from hummocks and 156.2 from the edges of pools (a 30-fold difference). Sites 7 and 15 were lower in overall fluxes $\left(5.2-5.5 \mathrm{mg} \cdot \mathrm{m}^{-2} \cdot \mathrm{d}^{-1}\right.$ site means) with very low hummock values $(0.2-1.8)$ and slightly higher hollow fluxes $\left(11.4-12.2 \mathrm{mg} \cdot \mathrm{m}^{-2} \cdot \mathrm{d}^{-1}\right)$. The main difference among sites was the high flux from the pool edges at site 1 where the mean depth to water table was less $(4.1 \mathrm{~cm})$ compared to that of the hollows in sites 7 and 15 (16.8 and $31.9 \mathrm{~cm}$, respectively). Treed bogs (sites 9 and 14) had low seasonal fluxes $\left(6.4\right.$ and $3.7 \mathrm{mg} \cdot \mathrm{m}^{-2} \cdot \mathrm{d}^{-1}$, respectively) with a fivefold difference in fluxes between hummocks and hollows, similar to the open bog sites 7 and 15.

All but one of the open and treed fens, including poor fens, had similar mean $\mathrm{CH}_{4}$ fluxes ranging from 21 to $44 \mathrm{mg} \cdot \mathrm{m}^{-2} \cdot \mathrm{d}^{-1}$ (sites $3,4,5$, and 6$)$. The hum- 
TABLE 4. Methane flux $\left(\mathrm{mg} \cdot \mathrm{m}^{-2} \cdot \mathrm{d}^{-1}\right)$ statistics for the 1991 season (May-October). Sites 1-15 are referenced in Table 2. Sites 16-19 are four beaver ponds in ascending position along a stream.

\begin{tabular}{|c|c|c|c|c|c|c|c|c|c|c|c|c|c|}
\hline \multirow[b]{3}{*}{ Site } & & & & \multirow[b]{3}{*}{ Median } & \multicolumn{9}{|c|}{ Microtopographic groupings } \\
\hline & \multicolumn{3}{|c|}{ Site } & & \multicolumn{3}{|c|}{ Hummock } & \multicolumn{3}{|c|}{ Hollow } & \multicolumn{3}{|c|}{ Lawn } \\
\hline & Mean & $\mathrm{SE}$ & $n$ & & Mean & $\mathrm{SE}$ & $n$ & Mean & $\mathrm{SE}$ & $n$ & Mean & SE & $n$ \\
\hline 1 & 67.5 & 6.7 & 300 & 16.1 & 5.1 & 0.5 & 102 & 156.2 & 14.5 & 91 & 30.3 & 8.1 & 107 \\
\hline 2 & 2.1 & 0.2 & 361 & 0.8 & 0.5 & 0.1 & 124 & 2.8 & 0.3 & 130 & 3.2 & 0.4 & 107 \\
\hline 3 & 33.2 & 2.7 & 357 & 13.8 & 3.8 & 0.5 & 134 & 61.1 & 5.6 & 124 & 32.6 & 3.4 & 99 \\
\hline 4 & 21.3 & 1.9 & 355 & 6.3 & 0.6 & 0.2 & 133 & 34.6 & 3.4 & 135 & 29.9 & 4.5 & 87 \\
\hline 5 & 32.6 & 3.5 & 251 & 13.1 & 3.1 & 1.9 & 80 & 56.3 & 6.4 & 83 & 29.3 & 5.3 & 88 \\
\hline 6 & 44.1 & 3.3 & 400 & 26.2 & 2.5 & 0.7 & 137 & 72.6 & 4.9 & 159 & 22.7 & 3.6 & 104 \\
\hline 7 & 5.5 & 0.6 & 372 & 0.8 & 0.2 & 0.2 & 135 & 12.2 & 1.2 & 131 & 3.2 & 0.8 & 106 \\
\hline 8 & 55.7 & 9.2 & 269 & 6.9 & 5.9 & 2.6 & 101 & 109.1 & 18.7 & 95 & 19.2 & 4.9 & 73 \\
\hline 9 & 6.4 & 0.5 & 342 & 3.6 & 2.2 & 0.2 & 127 & 11.1 & 1.0 & 148 & 3.8 & 0.4 & 67 \\
\hline 10 & 4.4 & 1.4 & 38 & 2.7 & & $\ldots$ & & & $\ldots$ & & & $\ldots$ & \\
\hline 11 & 91.1 & 29.2 & 38 & 29.7 & & $\ldots$ & & & $\cdots$ & & & $\cdots$ & \\
\hline 12 & 349.8 & 46.5 & 38 & 277.3 & & $\ldots$ & & & $\ldots$ & & & $\ldots$ & \\
\hline 13 & 0.4 & 0.1 & 225 & 0.2 & 0.1 & 0.1 & 82 & 0.5 & 0.2 & 77 & 0.3 & 0.1 & 66 \\
\hline 14 & 3.7 & 0.8 & 341 & 2.1 & 1.2 & 0.4 & 118 & 5.3 & 0.6 & 105 & 5.2 & 1.2 & 118 \\
\hline 15 & 5.2 & 0.8 & 327 & 4.6 & 1.8 & 0.3 & 143 & 11.4 & 1.2 & 103 & 7.3 & 1.2 & 81 \\
\hline 16 & 919 & 259 & 7 & 234 & & $\ldots$ & & & $\ldots$ & & & $\ldots$ & \\
\hline 17 & 136 & 25 & 20 & 111 & & $\ldots$ & & & $\ldots$ & & & $\ldots$ & \\
\hline 18 & 365 & 515 & 12 & 149 & & $\ldots$ & & & $\ldots$ & & & $\ldots$ & \\
\hline 19 & 147 & 27 & 19 & 98 & & $\ldots$ & & & $\ldots$ & & & $\ldots$ & \\
\hline
\end{tabular}

mock fluxes ranged from 0.6 to $3.8 \mathrm{mg} \cdot \mathrm{m}^{-2} \cdot \mathrm{d}^{-1}$ while hollows were significantly higher at $34.6-72.6$ $\mathrm{mg} \cdot \mathrm{m}^{-2} \cdot \mathrm{d}^{-1}$. These sites had the largest difference between hummock and hollow $\mathrm{CH}_{4}$ fluxes, with hollows 18 times higher than hummocks at site 5 (poor fen), to as much as a 58 -fold difference at the treed fen (site 4). The only fen with low fluxes was site 13 , an open rich fen and driest of all the sites, with hummock flux of 0.1 and hollow flux of $0.5 \mathrm{mg} \cdot \mathrm{m}^{-2} \cdot \mathrm{d}^{-1}$. This site had the largest difference between hummock and hollow water table position $(60 \mathrm{~cm})$, but the fluxes were still low overall, possibly because the hollow water tables were below a critical level for $\mathrm{CH}_{4}$ emission.

The two conifer swamps, which were very different in their ecological attributes, were also different in $\mathrm{CH}_{4}$ emissions. Site 2, the nutrient-poor, dry swamp had a mean $\mathrm{CH}_{4}$ flux of $2.1 \mathrm{mg} \cdot \mathrm{m}^{-2} \cdot \mathrm{d}^{-1}$ with 0.8 and 2.8 $\mathrm{mg} \cdot \mathrm{m}^{-2} \cdot \mathrm{d}^{-1}$ in the hummocks and hollows, respectively. Site $8 \mathrm{had}$ a mean flux of $55.7 \mathrm{mg} \cdot \mathrm{m}^{-2} \cdot \mathrm{d}^{-1}$ with an 18 -fold difference between hollows (109.1) and hummocks (5.9).

\section{Seasonal patterns in $\mathrm{CH}_{4}$ flux, water table, and soil temperature}

Figs. 3-5 show the seasonal pattern of $\mathrm{CH}_{4}$ flux, water table position, and soil temperature at $20 \mathrm{~cm}$. The three sites $(7,4$, and 8$)$ are representative of three common patterns observed among the sites. The $\mathrm{CH}_{4}$ flux figures are means of all measurements from 36 chambers per sampling day since no diurnal variation was observed and the patterns for the two sampling data sets were similar. Each wetland shows the large difference between hummocks and hollows. In general, hummocks had very low $\mathrm{CH}_{4}$ emissions with a slight.

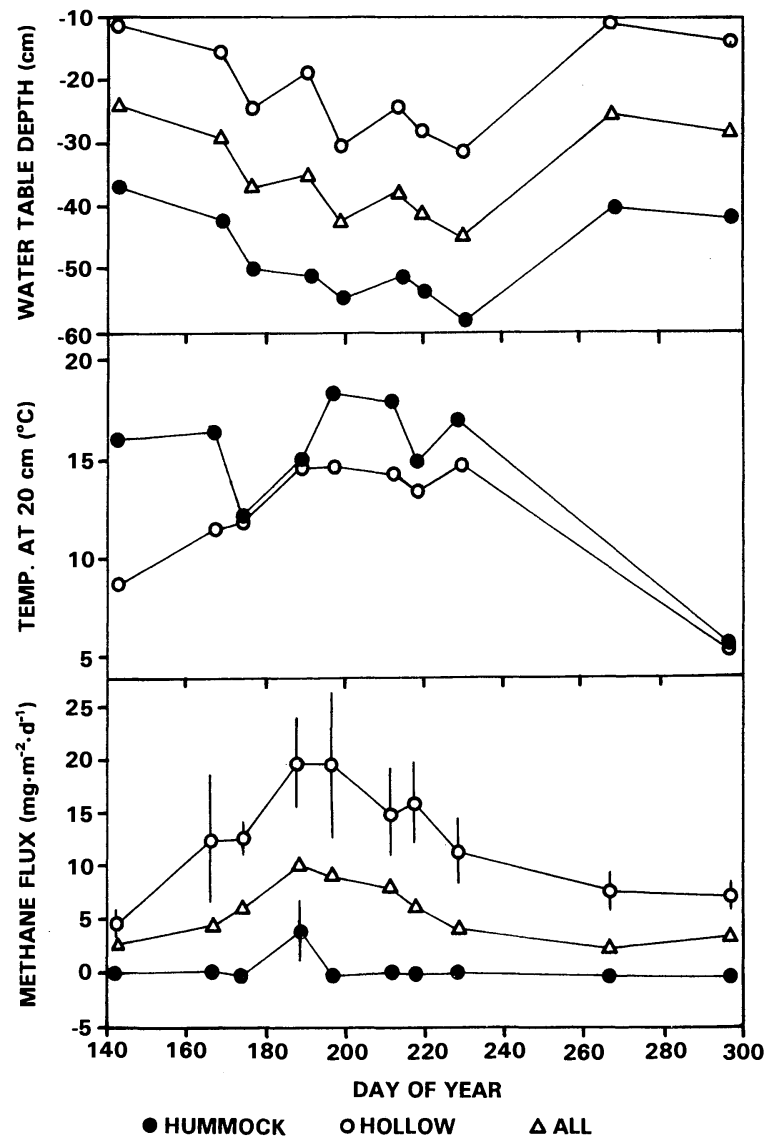

FIG. 3. Seasonal patterns of mean water table depth, soil temperature at $20 \mathrm{~cm}$ depth, and $\mathrm{CH}_{4}$ flux for site 7 , an open low shrub bog, by hummock and hollow groupings. Bars in the bottom graph show $\pm 1 \mathrm{SE}$. 


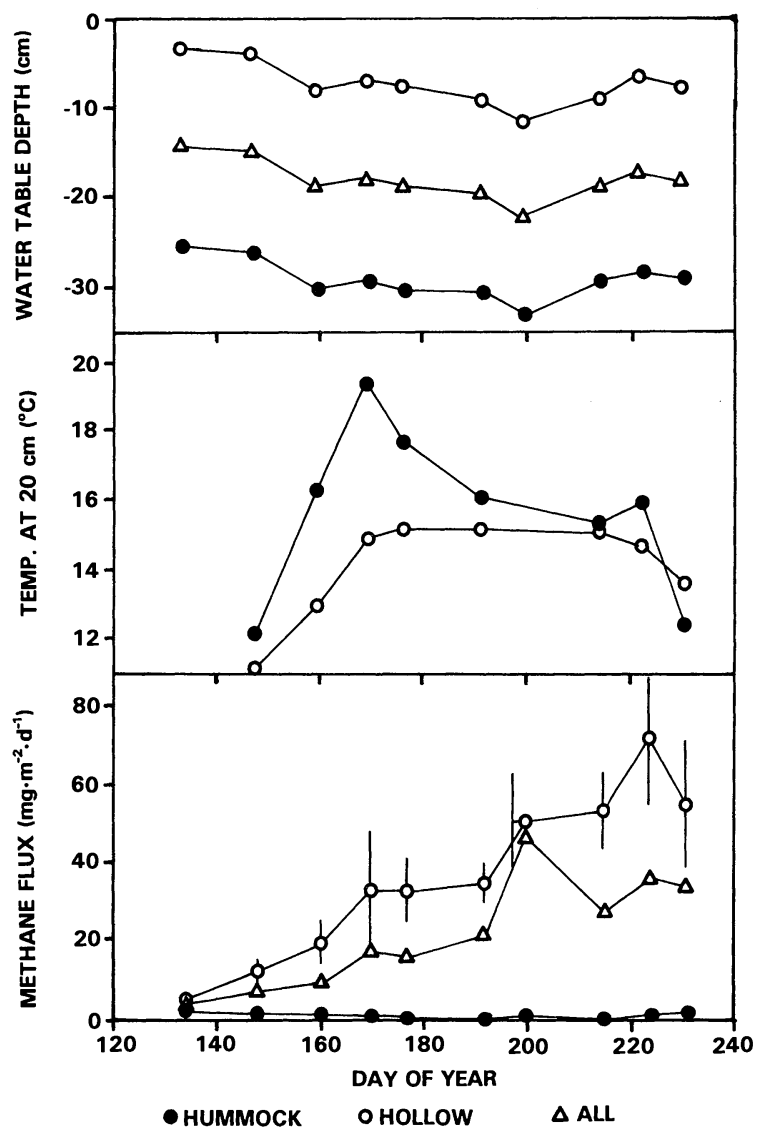

FIg. 4. Seasonal patterns for site 4 , a treed low shrub fen. Data presentation as in Fig. 3.

peak around day 185. The seasonal pattern of lawn fluxes was similar to that of hollows, but values were lower, except at site 4 .

The fluxes from hollows fell into three main patterns.

Pattern 1: At sites 1, 2, 5, 6, 7, and 14 (represented by site 7, an open low shrub bog, in Fig. 3), $\mathrm{CH}_{4}$ flux was very low in May and gradually rose to a peak around day $180-200$, then fell gradually until the end of August. In September, $\mathrm{CH}_{4}$ flux rose again at sites 6 and 14, then fell in October. At site 7, however, emissions remained low throughout September and October. The seasonal rise in $\mathrm{CH}_{4}$ flux at these sites generally coincided with a steady drop in the water table (Fig. 3). The water table difference between hummocks and hollows stayed relatively uniform throughout the season with a 15-20 cm change between the highest water table positions in May and September and the lowest in early August. The soil temperature pattern represented by site 7 (Fig. 3) showed that hummocks and hollows varied a great deal from each other throughout the season. The hummock temperatures at $20 \mathrm{~cm}$ fluctuated widely with no obvious pattern, perhaps in response to fluctuating daily air temperatures. The hollows showed a more gradual rise throughout the season with a peak around day 190 , similar to the $\mathrm{CH}_{4}$ flux pattern in the hollows.

Pattern 2: Fig. 4 shows the pattern typical of sites 3, 4, and 9, two fens and one bog. Hummock $\mathrm{CH}_{4}$ fluxes remained extremely low throughout the season, while hollow fluxes rose steadily from day 130 until day 230 . The peak hollow fluxes were later by 10-20 d from that in the above Pattern 1 (Fig. 3). The water table patterns showed a drop in water level in both hummocks and hollows, but only by $\approx 7 \mathrm{~cm}$ compared with a much larger drop in Fig. 3. Soil temperatures were similar to those described above in that hollow temperatures rose steadily, but peaked earlier at day 180 . Hummock temperatures peaked around the same day, but dropped sharply after that.

Pattern 3: Site 8 (Fig. 5), the rich conifer swamp, was the only site where the water table did not drop appreciably during the season. As in other sites, hummocks and hollows showed the same seasonal pattern in relation to each other. The soil temperature, however, was markedly different between the microtopographic units. Hummock temperatures at $20 \mathrm{~cm}$ were variable with the peak at day 170 , while hollow tem-

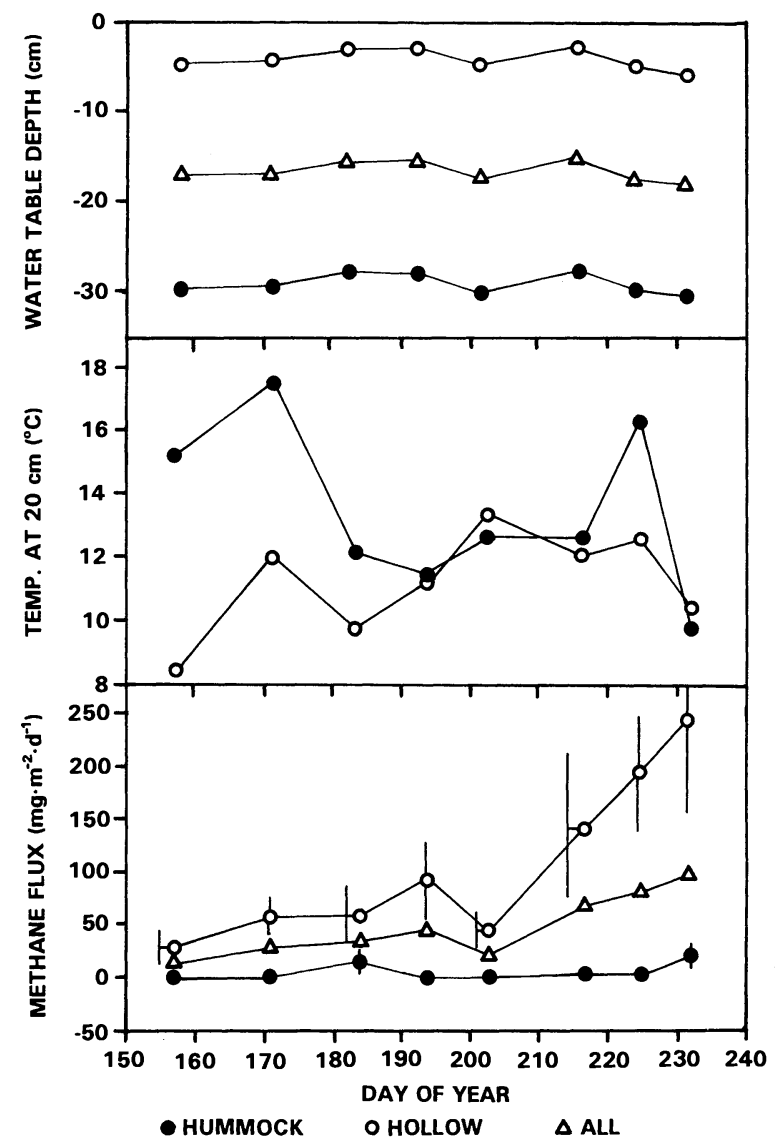

Fig. 5. Seasonal patterns for site 8, a conifer swamp. Data presentation as in Fig. 3. 
peratures rose more evenly with a peak around day 205 and dropping afterward. The seasonal flux pattern was also different at site 8 (Fig. 5). Unlike other sites where hollow $\mathrm{CH}_{4}$ emissions rose steadily from the beginning of the season, peaked between day 180 and 220, then fell, the hollow $\mathrm{CH}_{4}$ flux at site 8 rose until day 195, dropped slightly, then rose dramatically until the end of the sampling period at the end of August. As in other sites, the hummock fluxes remained very low throughout the season.

\section{Beaver ponds and adjacent marsh}

The results from testing two sampling durations, 2 $h$ and $10 \mathrm{~d}$, showed that the exposure period for the chambers significantly affected the observed flux rate. The average $\mathrm{CH}_{4}$ flux calculated from the 2-h exposure of the chambers floating on the ponds was $291 \pm 55$ $\mathrm{mg} \cdot \mathrm{m}^{-2} \cdot \mathrm{d}^{-1}$ (mean $\left.\pm 1 \mathrm{sE} ; n=59\right)$, whereas the average based on the accumulation of methane over a $10-\mathrm{d}$ period was $37 \pm 8 \mathrm{mg} \cdot \mathrm{m}^{-2} \cdot \mathrm{d}^{-1}(n=38)$. This eightfold difference suggests that measurements that entail leaving the chamber exposed for periods greater than a day at these high flux rates may seriously underestimate the $\mathrm{CH}_{4}$ flux, either through oxidation of methane within the chamber and water surface, or resolution of the methane from the chamber to the water, after a period of high emission rates.

$\mathrm{CH}_{4}$ fluxes determined from the water $\mathrm{CH}_{4}$ concentrations and wind speed ranged from 2 to 342 $\mathrm{mg} \cdot \mathrm{m}^{-2} \cdot \mathrm{d}^{-1}$. These values were much lower than the fluxes observed in the floating chambers at the same time. The ratio between the aerodynamic and chamber methods averaged 0.11 and 0.21 for the Crusius and Wanninkhof (in press) and Sebacher et al. (1983) methods, respectively, suggesting that in these beaver ponds, the dominant transport mechanism for $\mathrm{CH}_{4}$ is ebullition.

There were large differences in the $\mathrm{CH}_{4}$ flux rates measured at the ponds over the season (Table 4) with mean seasonal fluxes of $919,136,365$, and 147 $\mathrm{mg} \cdot \mathrm{m}^{-2} \cdot \mathrm{d}^{-1}$, in ascending position within the pond complex. The $\mathrm{CH}_{4}$ emissions from the marsh transect were $4.4-349.8 \mathrm{mg} \cdot \mathrm{m}^{-2} \cdot \mathrm{d}^{-1}$, from the dry to wet end of the gradient. The wet inundated edge of the pond (site 12) produced the highest seasonal flux, and this is also the area that is most susceptible to disturbance from beaver pond expansion and contraction.

\section{Calculation of regional $\mathrm{CH}_{4}$ flux from Clay Belt wetlands}

The annual mean flux at each site was determined by taking the seasonal mean flux and applying a season length of $150 \mathrm{~d}$ (mid-May to mid-October), the approximate period of $\mathrm{CH}_{4}$ emission in this study. For wetland classes with more than one $\mathrm{CH}_{4}$ sampling site, equal weight was given to each site. The annual fluxes for each wetland subformation (e.g., open bog, treed fen) were then given an areal weighting according to the average proportion of each wetland type in the Ontario Peatland Inventory (Riley 1987; Table 1). The only wetland type not sampled in this study was the thicket swamp. Since beaver ponds were not surveyed in the Ontario inventory, we estimated beaver pond coverage by mapping their distribution over $100 \mathrm{~km}^{2}$ on 1979 air photographs at a scale of 1:15000. The average coverage of beaver ponds was $0.19 \%$. Since wetlands are estimated to cover $21 \%$ of the Clay Belt region (Riley 1987), we estimated that beaver ponds cover $1 \%$ of the wetlands.

Results (Table 5) show that the estimated habitatweighted $\mathrm{CH}_{4}$ flux from the Clay Belt wetlands is 3.4 $\mathrm{g} \cdot \mathrm{m}^{-2} \cdot \mathrm{yr}^{-1}$. Assuming $21 \%$ wetland coverage, the flux for the entire Clay Belt region is $0.71 \mathrm{~g} \cdot \mathrm{m}^{-2} \cdot \mathrm{yr}^{-1}$. Almost half of the emissions come from conifer swamps, which cover $58 \%$ of the peatland area. However, because of the large difference in ecological types within the conifer swamp class (Jeglum 1991), the areal estimate of wet vs. dry swamps may be skewed either high or low by $50 \%$ or more (J. Jeglum, personal communication). Marshes and beaver ponds are the largest contributors by wetland type, but their significance is reduced by low areal coverage in the Clay Belt. The relative importance of bogs and fens is low compared with conifer swamps even though there is high variability within these formations due to different hydrologic regimes.

There are three possible sources of error in this regional estimate of methane emissions from the Clay Belt: sampling error, over- or underestimation of areal wetland coverage, and classification errors. These have been estimated as follows: (1) The error in sampling was calculated as a percentage of the annual flux based on the standard error of the seasonal mean flux values. This error estimate is probably low because the accumulation of standard error on a daily basis would be higher. There is also error in assuming the seasonal pattern of $\mathrm{CH}_{4}$ emission is $150 \mathrm{~d}$. Winter fluxes may not be insignificant (Dise 1992). (2) Roulet et al. (1992) determined the error associated with areal wetland coverage to be $\approx 15 \%$ for low boreal wetlands. Since the remote sensing and ground-truthing techniques were the same for the Clay Belt region as used in Roulet et al. (1992), we used the same error figure. (3) Errors due to broad-scale classification without the detail needed for $\mathrm{CH}_{4}$ flux purposes can be substantial, especially when there are extreme hydrologic differences within a formation. We estimated up to $50 \%$ error in the conifer swamp, open bog, and open fen subformations as a result of the different moisture regimes found at the $\mathrm{CH}_{4}$ sampling sites.

The three types of errors were added for each formation and a percentage error of the spatially weighted flux was determined. The errors from each wetland group were added to arrive at a total error estimate for the region. The combined error estimate was calculated at $56 \%$ for the annual $\mathrm{CH}_{4}$ flux from the Clay Belt 
TABLE 5. Area-weighted annual $\mathrm{CH}_{4}$ flux $\left(\mathrm{g} \cdot \mathrm{m}^{-2} \cdot \mathrm{yr}^{-1}\right)$ for Canadian midboreal wetlands according to wetland fractions of the Ontario Clay Belt in Table 1. Annual fluxes are based on $150 \mathrm{~d}$. The open fen class includes open poor fen. Thicket swamps (12\% of the total wetland area) were not sampled in this study.

\begin{tabular}{|c|c|c|c|c|}
\hline $\begin{array}{l}\text { Wetland } \\
\text { type }\end{array}$ & $\begin{array}{l}\text { Sites } \\
\text { sam- } \\
\text { pled }\end{array}$ & $\begin{array}{l}\text { Annu- } \\
\text { al } \\
\text { flux }\end{array}$ & $\begin{array}{c}\text { Frac- } \\
\text { tion of } \\
\text { wet- } \\
\text { lands }\end{array}$ & $\begin{array}{l}\text { Habitat- } \\
\text { weighted } \\
\text { flux }\end{array}$ \\
\hline Beaver pond & 4 & 58.8 & 0.010 & 0.588 \\
\hline \multicolumn{5}{|c|}{ Conifer swamp } \\
\hline $\begin{array}{l}\text { Dry } \\
\text { Wet }\end{array}$ & $\begin{array}{l}1 \\
1\end{array}$ & $\begin{array}{l}0.4 \\
5.2\end{array}$ & $\begin{array}{l}0.290 \\
0.290\end{array}$ & $\begin{array}{l}0.116 \\
1.508\end{array}$ \\
\hline \multicolumn{5}{|l|}{ Open bog } \\
\hline $\begin{array}{l}\text { W/o pools } \\
\text { With pools }\end{array}$ & $\begin{array}{l}2 \\
1\end{array}$ & $\begin{array}{l}0.8 \\
8.3\end{array}$ & $\begin{array}{l}0.026 \\
0.026\end{array}$ & $\begin{array}{l}0.021 \\
0.216\end{array}$ \\
\hline Treed bog & 2 & 0.7 & 0.158 & 0.111 \\
\hline \multicolumn{5}{|l|}{ Open fen } \\
\hline $\begin{array}{l}\text { Dry } \\
\text { Wet }\end{array}$ & $\begin{array}{l}1 \\
3\end{array}$ & $\begin{array}{l}0.03 \\
5.1\end{array}$ & $\begin{array}{l}0.012 \\
0.012\end{array}$ & $\begin{array}{l}0.001 \\
0.061\end{array}$ \\
\hline Treed fen & 1 & 4.3 & 0.035 & 0.151 \\
\hline \multirow[t]{2}{*}{ Marsh } & 1 & 22.4 & 0.027 & 0.605 \\
\hline & & & & $\begin{array}{l}3.378 \text { total } \\
1.473-5.281 \text { range }\end{array}$ \\
\hline
\end{tabular}

wetlands. This means that habitat-weighted annual $\mathrm{CH}_{4}$ emissions could range from 1.47 to $5.28 \mathrm{~g} \cdot \mathrm{m}^{-2} \cdot \mathrm{yr}^{-1}$.

\section{Discussion}

\section{Correlations with environmental variables}

Weak relationships between $\mathrm{CH}_{4}$ flux and single environmental variables within sites are understandable for a variety of reasons. Episodic fluxes have been reported in subarctic fens (Windsor et al. 1992) especially in a spring pulse, releasing methane trapped in the ice during the winter. These episodes may also occur after a drop in the water table midsummer, perhaps due to decreases in atmospheric pressure at the peat surface (Mattson and Likens 1990), increased methane diffusivity, or reduced rates of methane consumption in the surface layers of the peat. This study, as well as others (Moore et al. 1990, Moore and Roulet 1991), found that $\mathrm{CH}_{4}$ flux increases as the water table drops during the season. This suggests either a greater influence of temperature on the seasonal pattern or factors associated with episodic methane release following drops in the water table. The spatial difference between hummocks and hollows within sites indicates water table position as an important control. Lag effects between water table, temperature, and $\mathrm{CH}_{4}$ flux may partly explain these phenomena. In addition, laboratory studies have shown different temperature responses of methane production and oxidation (Dunfield et al. 1993).

Whalen and Reeburgh (1992) concluded that parameters that integrate conditions influencing $\mathrm{CH}_{4}$ flux appear to be the best predictors. This study finds that mean water table position is the best predictor (Fig. 2); therefore, variables that are either directly or indirectly related to water table will be the most useful for regional extrapolations. Bryophytes are sensitive indicators of average water table position on a smaller scale than most vascular plants (Vitt and Bayley 1984, Andrus 1986, Gignac and Vitt 1990) and hold promise for use as predictors for certain ranges of $\mathrm{CH}_{4}$ flux. In this study, Sphagnum fuscum dominated most of the hummocks and indicated very low fluxes, while species such as $S$. cuspidatum, $S$. majus, Cratoneuron filicinum, and Warnstorfia exannulatus were wet hollow indicators and corresponded with the highest flux values.

Hollows emitted 5-60 times more methane than hummocks. Yet it appeared that there was a critical water table depth, below which little flux occurred. All the hummocks in this study had seasonal mean water table depths of $25 \mathrm{~cm}$ or greater and yielded no more than $5.9 \mathrm{mg} \cdot \mathrm{m}^{-2} \cdot \mathrm{d}^{-1}$ (Tables 3 and 4 ). The hollow fluxes were $<12 \mathrm{mg} \cdot \mathrm{m}^{-2} \cdot \mathrm{d}^{-1}$ when the water table was $>18 \mathrm{~cm}$ below the surface. However, when the water table was within $12 \mathrm{~cm}$ of the peat surface, $\mathrm{CH}_{4}$ fluxes were $>35 \mathrm{mg} \cdot \mathrm{m}^{-2} \cdot \mathrm{d}^{-1}$ and as high as $349 \mathrm{mg} \cdot \mathrm{m}^{-2} \cdot \mathrm{d}^{-1}$ as the water table approached or exceeded the peat surface.

The designation of hummock or hollow was less important than actual water table position as evidenced by comparably small $\mathrm{CH}_{4}$ fluxes in hollows at site 13 $\left(0.5 \mathrm{mg} \cdot \mathrm{m}^{-2} \cdot \mathrm{d}^{-1}\right)$ and hummocks at site $3(3.8$ $\mathrm{mg} \cdot \mathrm{m}^{-2} \cdot \mathrm{d}^{-1}$ ) where the mean water table positions were similar. It appeared that when the water table was $18-20 \mathrm{~cm}$ below the surface on average, fluxes decreased dramatically, indicating either a reduction in production, increase in consumption, or both. Moore et al. (in press) incubated peat samples under aerobic and anaerobic conditions and found different $\mathrm{CH}_{4}$ oxidation and production rates at different peat depths from samples taken from the Hudson Bay Lowlands. At a depth of 10-20 cm, production and consumption rates were high; but at $0-10 \mathrm{~cm}$, production rates were low and consumption rates were still high.

Substrate characteristics, perhaps controlled by water table depths and relative populations of methanogens and methanotrophs may have a significant effect on methane emissions. Williams and Crawford (1984) found that different types of plant material can also affect production and oxidation rates, which may influence $\mathrm{CH}_{4}$ flux in hummocks and hollows. Field measurements from this study suggest that $18-20 \mathrm{~cm}$ may be a critical depth for changes in substrate conditions for Clay Belt peatlands. Water table depth and bacterial populations had more effect on production and consumption rates than type of plant material in the peat (Bubier et al., in press).

Seasonal mean soil temperature did not explain differences in $\mathrm{CH}_{4}$ flux among the sites. Although other studies have found good statistical relationships 
TABLE 6. Estimated annual methane emission rates from beaver ponds and adjacent affected areas.

\begin{tabular}{|c|c|c|c|}
\hline Source & Location & Ecological site & $\begin{array}{c}\text { Annual } \\
\mathrm{CH}_{4} \text { flux } \\
\left(\mathrm{g} \cdot \mathrm{m}^{-2} \cdot \mathrm{yr}^{-1}\right)\end{array}$ \\
\hline Ford and Naiman (1988) & Sept-Iles, Quebec & $\begin{array}{l}\text { Undisturbed stream } \\
\text { Beaver pond }\end{array}$ & $\begin{array}{c}0.1-0.4 \\
5.9\end{array}$ \\
\hline Vitt et al. (1990) & central Alberta & Beaver pond & 76.2 \\
\hline Yavitt et al. (1990) & W. Virginia, Maryland & Beaver pond & $300,250^{*}$ \\
\hline Naiman et al. (1991) & northern Minnesota & $\begin{array}{l}\text { Upland forest } \\
\text { Sedge meadow } \\
\text { Submergent }(45 \mathrm{~cm} \text { water }) \\
\text { Deep pond }(125 \mathrm{~cm} \text { water })\end{array}$ & $\begin{array}{r}0.3 \\
0.5 \\
14.3 \\
11.6\end{array}$ \\
\hline Roulet et al. (1992) & southern Ontario & Beaver pond & 7.6 \\
\hline Weyhenmeyer (1992) & southern Ontario & Beaver pond & 6.2 \\
\hline Yavitt et al. (1992) & Adirondacks, New York & Beaver ponds & $34-40$ \\
\hline J. Windsor (unpublished data) & southern Quebec & $\begin{array}{l}\text { Submerged margin }(5-10 \mathrm{~cm} \text { water }) \\
\text { Shallow water }(15-50 \mathrm{~cm})\end{array}$ & $\begin{array}{l}42.0 \\
53.6\end{array}$ \\
\hline This study & northern Ontario & $\begin{array}{l}\text { Marsh }(-18 \mathrm{~cm} \text { water }) \\
\text { Marsh }(-3 \mathrm{~cm} \text { water }) \\
\text { Submerged }(5 \mathrm{~cm} \text { water }) \\
\text { Deep water }(50-150 \mathrm{~cm} \text { water })\end{array}$ & $\begin{array}{r}0.7 \dagger \\
13.4 \dagger \\
52.5 \dagger \\
43.7 \dagger\end{array}$ \\
\hline
\end{tabular}

* Daily $\mathrm{CH}_{4}$ flux $\left(\mathrm{mg} \cdot \mathrm{m}^{-2} \cdot \mathrm{d}^{-1}\right)$ reported at two dates, expressed as mean and median.

$\dagger$ Assuming a season of $150 \mathrm{~d}$, for which the rates from early June to mid-August were representative, and no significant emission of methane during the winter.

(Svensson and Rosswall 1984, Harriss et al. 1985, Crill et al. 1988, Morrissey and Livingston 1992), this study and others (Moore et al. 1990, Roulet et al. 1992, Dise et al., in press, Moore et al., in press) found that water table position is a better correlate. One possible explanation is that temperature and water table are not independent variables because moisture regime controls both the thermal conductivity and the heat capacity of the peat and sediment (Oke 1987). Also, methane production and oxidation may be more closely tied with anaerobic or aerobic soil conditions, with soil temperature having a secondary effect (T. R. Moore and M. Dalva, unpublished manuscript).

Laboratory studies have shown than methane production and consumption are $\mathrm{pH}$ dependent with optimum pH values of 5 and 7 for subarctic and temperate peats (Dunfield et al. 1993) although acidtolerant strains have been reported (Williams and Crawford 1985, Patel et al. 1990). Field studies (Moore and Knowles 1990, Moore et al., in press) show, however, that soil $\mathrm{pH}$ has relatively little effect on methane emissions and this study confirms that finding. The highest fluxes reported here were from pools at the raised bog ( $\mathrm{pH} 4.0)$ similar to that reported in the Hudson Bay Lowlands (Moore et al., in press) and in the marsh adjacent to the beaver pond (pH 6.1). Conversely, the lowest fluxes were also from sites that represented the most and least acid conditions. Site 13, a rich fen ( $\mathrm{pH}$ 6.3) and site 2, a poor conifer swamp (pH 4.1) had seasonal $\mathrm{CH}_{4}$ fluxes of 0.4 and 2.1 $\mathrm{mg} \cdot \mathrm{m}^{-2} \cdot \mathrm{d}^{-1}$.

\section{Beaver ponds}

There has been discussion on the role of beaver in influencing $\mathrm{CH}_{4}$ emission rates from boreal wetlands, and the possible role of beaver population fluctuations on the global $\mathrm{CH}_{4}$ budget (e.g., Naiman et al. 1986, 1988, 1991, Ford and Naiman 1988, Vitt et al. 1990, Roulet et al. 1992, Yavitt et al. 1992). Several studies have measured $\mathrm{CH}_{4}$ emissions from boreal beaver ponds and there is great variation in the annual emission estimates (Table 6). All estimates contain a great deal of uncertainty, because of the high spatial variability in emission rates when sampled, lack of data from the winter season, and the occurrence of episodic emissions, possibly associated with low atmospheric pressures (e.g., Mattson and Likens 1990).

The difference in $\mathrm{CH}_{4}$ flux determined by floating chambers exposed for $2 \mathrm{~h}$ and $10 \mathrm{~d}$ in the present study suggests that caution should be used in extrapolating data collected over long exposure periods (e.g., Ford and Naiman 1988, Naiman et al. 1991). The small diffusive flux of $\mathrm{CH}_{4}$ calculated from concentration and wind speed data, compared to the measurements made by chambers, suggests that ebullition is the dominant flux mechanism. In a study of southern Ontario beaver ponds, $\approx 65 \%$ of the methane flux was attributed to ebullition (Weyhenmeyer 1992). The present study, along with that of Naiman et al. (1991), has also demonstrated that the raising of the water table in organic soils adjacent to the beaver pond can result in large $\mathrm{CH}_{4}$ fluxes. Other studies, such as Bartlett et al. (1992), Morrissey and Livingston (1992), and Whalen and 
Reeburgh (1988), have shown that pond edges can emit large amounts of $\mathrm{CH}_{4}$.

Data on the coverage of beaver ponds and their adjacent waterlogged soils are still sparse. We estimated the present coverage of beaver ponds as $1 \%$ of the wetlands in the Clay Belt, lower than the $7 \%$ observed by Roulet et al. (1992) in the low boreal region of southern Ontario and $1.9 \%$ reported in boreal Alberta (Vitt et al. 1990). In the Kabetogama Peninsula of Minnesota, Naiman et al. (1988) reported an increase in beaver pond coverage of $1-13 \%$ of the total area from 1940 to 1986 , illustrating the dynamic nature of this phenomenon. Better regional estimates of $\mathrm{CH}_{4}$ flux will depend on improved measurements from beaver ponds and estimates of their historical and contemporary coverage.

\section{Regional and global $\mathrm{CH}_{4}$ estimates}

The regional methane flux estimate of $3.4 \mathrm{~g} \cdot \mathrm{m}^{-2} \cdot \mathrm{yr}^{-1}$ from the Clay Belt wetlands has inherent errors as discussed above. The most serious source of error for the boreal region, however, is the difficulty of estimating $\mathrm{CH}_{4}$ flux with broad-scale classification systems as used in the Ontario Peatland Inventory (Riley 1987). This type of classification is best suited to large-scale estimates of peatland type by vegetation and trophic status (Zoltai 1988) across wide geographic areas, but is insufficient for estimating $\mathrm{CH}_{4}$ flux.

In the Clay Belt, conifer swamps are the dominant peatland, yet they show the widest range in ecological attributes and seasonal $\mathrm{CH}_{4}$ flux. We estimated that the error associated with diversity of conifer swamps alone was responsible for $43 \%$ of the total error in annual flux estimates for the Clay Belt. For classifications to be useful for methane prediction, they must incorporate hydrology and microtopography. Trophic status and overall physiognomy seem to have little effect. This is a particular problem for forested peatlands where understory vegetation, which is a better indicator of water table position than tree cover, is difficult to detect with current remote sensing techniques (Jeglum and Boissoneau 1977).

Although in general bogs were dry and fens were wet in this study, two notable exceptions of a bog with pool development (site 1) and a very dry shrub-rich fen (site 13) indicate that classification by physiognomy and chemical status of peatland waters is inadequate for other peatland formations as well. Bogs and fens were relatively unimportant in this study owing to their low areal coverage, but they are the dominant peatland types in other regions and are subject to the same classification difficulties as in this study.

Comparisons with other studies of $\mathrm{CH}_{4}$ flux from boreal wetlands indicate that the habitat-weighted annual flux of the Clay Belt is generally higher than that of low boreal wetlands in southern Ontario (Roulet et al. 1992). By habitat type, the fluxes from beaver ponds, conifer swamps, and marshes were higher in this study.
However, thicket swamps, which were a large source of $\mathrm{CH}_{4}$ emission in southern Ontario, were not measured in this study. The large range of fluxes for bogs, fens, and conifer swamps in this study encompass the range of fluxes for most other boreal wetlands (reviewed in Roulet et al. 1992), although fluxes from Minnesota bogs are consistently higher (e.g., Harriss et al. 1985, Crill et al. 1988, Dise 1993). Since the range of fluxes in this study was correlated with mean water table depth, hydrology may explain different fluxes from other boreal wetlands as well. In a collation of $\mathrm{CH}_{4}$ flux data from five wetland regions in boreal-subarctic Canada, Moore and Roulet (1993) reported a strong functional relationship between $\log \mathrm{CH}_{4}$ flux and mean water table position within all regional wetland landscapes. Although the regression coefficients were similar, there were differences in the regression constants among the regions. Differences in the capacity of the peat to produce and consume $\mathrm{CH}_{4}$ in laboratory incubations, rather that soil temperature, seemed to explain the regional differences.

\section{ACKNOWLEDGMENTS}

We would like to thank J. Riley and J. Jeglum for their advice on wetland classification for the Clay Belt; R. Ash, A. Costello, A. Heyes, W. Quinton, and K. Savage for laboratory and field assistance; J. Janssens for assistance with bryophyte identification; M. Lapointe for statistical advice; M. Lechowicz, M. Waterway and several anonymous reviewers for critically commenting on the manuscript; and the National Science and Engineering Research Council of Canada (Strategic Grant number STR 0045266), Max Bell Fellowships, the Switzer Foundation, and the Association of American Geographers for funding this research.

\section{Literature Cited}

Anderson, L. E. 1990. A checklist of Sphagnum in North America north of Mexico. Bryologist 93:500-501.

Anderson, L. E., H. A. Crum, and W. R. Buck. 1990. List of mosses of North America north of Mexico. Bryologist 93:448-499.

Andrus, R. E. 1986. Some aspects of Sphagnum ecology. Canadian Journal of Botany 64:416-426.

Aselmann, I., and P. J. Crutzen. 1989. Global distribution of natural freshwater wetlands and rice paddies, their net primary productivity, seasonality and possible methane emissions. Journal of Atmospheric Chemistry 8:307-358.

Bartlett, D. S., K. B. Bartlett, J. M. Hartman, R. C. Harriss, D. I. Sebacher, R. Pelletier-Travis, D. D. Dow, and D. P. Brannon. 1989. Methane emissions from the Florida Everglades: patterns of variability in a regional wetland ecosystem. Global Biogeochemical Cycles 3:363-374.

Bartlett, K. B., P. M. Crill, R. L. Sass, R. C. Harriss, and N. B. Dise. 1992. Methane emissions from tundra environments in the Yukon-Kuskokwim Delta, Alaska. Journal of Geophysical Research 97:16 645-16 660.

Boissoneau, A. N. 1966. Glacial history of Northeastern Ontario I, the Cochrane-Hearst area. Canadian Journal of Earth Sciences 3:559-578.

Bubier, J. L., A. Costello, T. R. Moore, N. T. Roulet, and K. Savage. In press. Microtopography and methane flux in boreal peatlands, northern Ontario, Canada. Canadian Journal of Botany.

Cicerone, R. J., and R. S. Oremland. 1988. Biogeochemical aspects of atmospheric methane. Global Biogeochemical Cycles 2:299-327. 
Crill, P. M., K. B. Bartlett, R. C. Harriss, E. Gorham, E. S. Verry, D. I. Sebacher, L. Madzer, and W. Sanner. 1988. Methane flux from Minnesota peatlands. Global Biogeochemical Cycles 2:371-384.

Crum, H. A. and L. E. Anderson. 1981. Mosses of eastern North America. Columbia University Press, New York, New York, USA.

Crusius, J., and R. H. Wanninkhof. In press. Refining the gas exchange-wind speed relationship at low wind speeds on Lake $302 \mathrm{~N}$ with $\mathrm{SF}_{6}$. Limnology and Oceanography.

Dise, N. B. 1992. Winter fluxes of methane from Minnesota peatlands. Biogeochemistry 17:71-83.

- 1993. Methane emission from Minnesota peatlands: spatial and seasonal variability. Global Biogeochemical $\mathrm{Cy}-$ cles 7:123-142.

Dise, N. B., E. Gorham, and E. S. Verry. In press. Environmental factors controlling methane emissions from peatlands in northern Minnesota. Journal of Geophysical Research.

Dunfield, P., R. Knowles, R. Dumont, and T. Moore. 1993. Methane production and consumption in temperate and subarctic peat soils: response to temperature and $\mathrm{pH}$. Soil Biology and Biochemistry 23:321-326.

Fechner, E. J., and H. F. Hemond. 1992. Methane transport and oxidation in the unsaturated zone of a Sphagnum peatland. Global Biogeochemical Cycles 6:33-44.

Fernald, M. L. 1950. Gray's manual of botany. Eighth edition (corrected). Van Nostrand, New York, New York, USA.

Ford, T. E., and R. J. Naiman. 1988. Alteration of carbon cycling by beaver: methane evasion rates from boreal forest streams and rivers. Canadian Journal of Zoology 6:529553.

Fung, I., J. John, J. Lerner, E. Matthews, M. Prather, L. Steele, and P. Fraser. 1991. Global budgets of atmospheric methane: results from a three-dimensional global model synthesis. Journal of Geophysical Research 6:13 033-13 065 .

Gignac, L. D., and D. H. Vitt. 1990. Habitat limitations of Sphagnum along climatic, chemical, and physical gradients in mires of western Canada. Bryologist 93:7-22.

Gignac, L. D., D. H. Vitt, S. C. Zoltai, and S. E. Bayley. 1991. Bryophyte response surfaces along climatic, chemical, and physical gradients in peatlands of western Canada. Nova Hedwigia 53:27-71.

Glaser, P. H. 1987. The ecology of patterned boreal peatlands of northern Minnesota: a community profile. Fish and Wildlife Service, U.S. Department of the Interior, Washington, D.C., USA.

Glaser, P. H., J. A. Janssens, and D. I. Siegel. 1990. The response of vegetation to chemical and hydrological gradients in the Lost River Peatland, northern Minnesota. Journal of Ecology 78:1021-1048.

Harriss, R. C., E. Gorham, D. I. Sebacher, K. B. Bartlett, and P. A. Flebbe. 1985. Methane flux from northern peatlands. Nature 315:652-654.

Janssens, J. A., B. C. Hansen, P. H. Glaser, and C. Whitlock. 1992. Development of a raised bog complex in northern Minnesota. In H. E. Wright Jr., B. Coffin, and N. Aasing, editors. Patterned peatlands of northern Minnesota. University of Minnesota Press, St. Paul, Minnesota, USA.

Jeglum, J. K. 1991. Definition of trophic classes in wooded peatlands by means of vegetation types and plant indicators. Acta Botanica Fennica 28:175-192.

Jeglum, J. K., and A. N. Boissonneau. 1977. Air photo interpretation of wetlands, Northern Clay section, Ontario. Environment Canada, Canadian Forestry Service, Great Lakes Forest Research Centre, Sault Sainte Marie, Ontario, Canada.

Khalil, M. A. K., and R. A. Rasmussen. 1989. Climateinduced feedbacks for the global cycles of methane and nitrous oxide. Tellus 41B:554-559.

Khalil, M. A. K., and R. A. Rasmussen. 1990. Constraints on the global sources of methane and an analysis of recent budgets. Tellus 42B:229-236.

King, G. M., P. Roslev, and H. Skovgaard. 1990. Distribution and rate of methane oxidation in sediments of the Florida Everglades. Applied and Environmental Microbiology 56:2902-2911.

Lindholm, T., and I. Markkula. 1984. Moisture conditions in hummocks and hollows in virgin and drained sites on the raised bog Laaviosuo, southern Finland. Annales Botanici Fennici 21:241-255.

Matthews, E., and I. Fung. 1987. Methane emission from natural wetlands: global distribution, area, and environmental characteristics of sources. Global Biogeochemical Cycles 1:61-86.

Mattson, M. D., and G. E. Likens. 1990. Air pressure and methane fluxes. Nature 347:718-719.

Moore, T. R., A. Heyes, and N. T. Roulet. In press. Methane emissions from wetlands, southern Hudson Bay Lowlands. Journal of Geophysical Research.

Moore, T. R., and R. Knowles. 1990. Methane emissions from fen, bog and swamp peatlands in Quebec. Biogeochemistry 11:45-61.

Moore, T. R., and N. Roulet. 1991. A comparison of dynamic and static chambers for methane emission measurements from subarctic fens. Atmosphere-Ocean 29:102109.

Moore, T. R., and N. T. Roulet. 1993. Methane flux: water table relations in northern wetlands. Geophysical Research Letters 20:587-590.

Moore, T., N. Roulet, and R. Knowles. 1990. Spatial and temporal variations of methane flux from subarctic/northern boreal fens. Global Biogeochemical Cycles 4:29-46.

Morrissey, L. A., and G. P. Livingston. 1992. Methane emissions from Alaskan arctic tundra: an assessment of local spatial variability. Journal of Geophysical Research 97: 16 661-16670.

Naiman, R. J., C. A. Johnston, and J. C. Kelley. 1988. Alteration of North American streams by beaver. BioScience 38:753-762.

Naiman, R. J., T. Manning, and C. A. Johnston. 1991. Beaver population fluctuations and tropospheric methane emissions in boreal wetlands. Biogeochemistry 12:1-15.

Naiman, R. J., J. M. Melillo, and J. E. Hobbie. 1986. Ecosystem alteration of a boreal forest stream by beaver (Castor canadensis). Ecology 67:1254-1269.

Oke, T. 1987. Boundary layer climatology. Second edition. Methuen, New York, New York, USA.

Patel, G. B., G. D. Sprott, and J. E. Fein. 1990. Isolation and characterization of Methanobacterium espanolae sp. nov., a mesophilic, moderately acidiphilic methanogen. International Journal of Systematic Bacteriology 40:12-18.

Riley, J. L. 1987. Peat and peatland resources of northeastern Ontario. Open File Report 5631. Ontario Geological Survey, Ministry of Northern Mines and Development, Toronto, Ontario, Canada

Roulet, N., R. Ash, and T. R. Moore. 1992. Low boreal wetlands as a source of atmospheric methane. Journal of Geophysical Research 97:3739-3749.

Roulet, N., A. Jano, C. A. Kelly, L. Klinger, T. R. Moore, R. Protz, J. A. Ritter, and W. R. Rouse. In press. The role of the Hudson Bay Lowland as a source of atmospheric methane. Journal of Geophysical Research.

Sebacher, D. I., R. C. Harriss, and K. B. Bartlett. 1983. Methane flux across the air-water interface: air velocity effects. Tellus 35B:103-109.

Sjörs, H. 1961. Forest and peatland at Hawley Lake, northern Ontario. Bulletin of the National Museum of Canada 171:1-31.

1963. Bogs and fens on Attawapiskat River, northern Ontario. Bulletin of the National Museum of Canada Contributions to Botany 186:45-133. 
Steele, L. P., E. J. Dlugokencky, P. M. Lang, P. P. Tans, R. C. Martin, and K. A. Masarie. 1992. Slowing down of the global accumulation of atmospheric methane during the 1980's. Nature 358:313-316.

Svensson, B. H., and T. Rosswall. 1984. In situ methane production from acid peat in plant communities with different moisture regimes in a subarctic mire. Oikos 43:341350.

Verry, E. S. 1984. Microtopography and water table fluctuation in a sphagnum mire. Pages $11-31$ in Proceedings of the Seventh International Peat Congress, Dublin, Ireland. Volume 2. International Peat Society, Helsinki, Finland.

Vitt, D. H., and S. Bayley. 1984. The vegetation and water chemistry of four oligotrophic basin mires in northwestern Ontario. Canadian Journal of Botany 62:1485-1500.

Vitt, D. H., S. Bayley, T. Jin, L. Halsey, B. Barker, and R. Craik. 1990. Methane and carbon dioxide production from wetlands in boreal Alberta. Report of Contract Number 900270, Alberta Environment Ministry, Edmonton, Alberta, Canada.

Vitt, D. H., and W.-L. Chee. 1990. The relationships of vegetation to surface water chemistry and peat chemistry in fens of Alberta, Canada. Vegetatio 89:87-106.

Weyhenmeyer, C. E. 1992. Methane emissions from a boreal beaver pond. Thesis. Trent University, Peterborough, Ontario, Canada.

Whalen, S. C., and W. S. Reeburgh. 1988. A methane flux time series for tundra environments. Global Biogeochemical Cycles 2:399-409.

Whalen, S. C., and W. S. Reeburgh. 1990. A methane flux transect along the trans-Alaska pipeline haul road. Tellus 42B:237-249.
Whalen, S. C., and W. S. Reeburgh. 1992. Interannual variations in methane emissions: a four-year time-series at fixed sites. Global Biogeochemical Cycles 6:139-159.

Whiting, G. J., and J. P. Chanton. 1992. Plant-dependent $\mathrm{CH}_{4}$ emission in a subarctic Canadian fen. Global Biogeochemical Cycles 6:225-231.

Williams, R. T., and R. L. Crawford. 1984. Methane production in Minnesota peatlands. Applied and Environmental Microbiology 47:1266-1271.

Williams, R.T., and R. L. Crawford. 1985. Methanogenic bacteria, including an acid-tolerant strain, from peatlands. Applied and Environmental Microbiology 50:1542-1544.

Windsor, J., T. R. Moore, and N. T. Roulet. 1992. Episodic fluxes of methane from subarctic fens. Canadian Journal of Soil Science 72:441-452.

Yavitt, J. B., L. L. Angell., T. J. Fahey, C. P. Cirmo, and C. T. Driscoll. 1992. Methane fluxes, concentrations, and production in two Adirondack beaver impoundments. Limnology and Oceanography 37:1057-1066.

Yavitt, J. B., G. E. Lang, and D. M. Downey. 1988. Potential methane production and methane oxidation rates in peatland ecosystems of the Appalachian Mountains, United States. Global Biogeochemical Cycles 2:253-268.

Yavitt, J. B., G. E. Lang, and A. J. Sexstone. 1990. Methane fluxes in wetland and forest soils, beaver ponds, and loworder streams of a temperate forest ecosystem. Journal of Geophysical Research 95:22 463-22 474.

Zoltai, S. C. 1988. Wetland environments and classification. Pages 3-26 in National Wetlands Working Group, editors. Wetlands of Canada. Ecological Land Classification Series, Number 24. Environment Canada, Ottawa, Ontario, and Polyscience Publications, Montreal, Quebec, Canada. 